\title{
The quintet completed: The partitioning of sulfur between nominally volatile-free minerals and silicate melts
}

\author{
Sara Callegaro ${ }^{1,2, *}, \mathrm{~K}$ alotina Gera K ${ }^{3}$, Andrea Marzoli ${ }^{1} \dagger$, Angelo de $\mathrm{M} \mathrm{IN}^{4}$, \\ VICTORIA MANETA ${ }^{5}$, AND DON R. BAKER ${ }^{5}$ \\ 'Department of Geosciences, University of Padova, via Gradenigo 6-35131 Padova, Italy \\ ${ }^{2}$ CEED — Centre for Earth Evolution and Dynamics, Sem Sælands vei 2A, 0371 Oslo, Norway \\ ${ }^{3}$ Diamond Light Source, Harwell Science and Innovation Campus, Didcot, OX11 0DE, U.K. \\ ${ }^{4}$ Department of Mathematics and Geoscience, University of Trieste, via Weiss 2, 34128 Trieste, Italy \\ ${ }^{5}$ Department of Earth and Planetary Sciences, McGill University, 3450 University Street, Montreal, Quebec, Canada
}

\section{ABSTRA CT}

Magmatic systems are dominated by five volatiles, namely $\mathrm{H}_{2} \mathrm{O}, \mathrm{CO}_{2}, \mathrm{~F}, \mathrm{Cl}$, and $\mathrm{S}$ (the igneous quintet). Multiple studies have measured partitioning of four out of these five volatiles $\left(\mathrm{H}_{2} \mathrm{O}, \mathrm{CO}_{2}, \mathrm{~F}\right.$, and $\mathrm{Cl}$ ) between nominally volatile-free minerals and melts, whereas the partitioning of sulfur is poorly known. To better constrain the behavior of sulfur in igneous systems we measured the partitioning of sulfur between clinopyroxene and silicate melts over a range of pressure, temperature, and melt composition from 0.8 to $1.2 \mathrm{GPa}, 1000$ to $1240{ }^{\circ} \mathrm{C}$, and 49 to $66 \mathrm{wt} \% \mathrm{SiO}_{2}$ (13 measurements). Additionally, we determined the crystal-melt partitioning of sulfur for plagioclase ( 6 measurements), orthopyroxene ( 2 measurements), amphibole ( 2 measurements), and olivine (1 measurement) in some of these same run products. Experiments were performed at high and low oxygen fugacities, where sulfur in the melt is expected to be dominantly present as an $\mathrm{S}^{6+}$ or an $\mathrm{S}^{2-}$ species, respectively. When the partition coefficient is calculated as the total sulfur in the crystal divided by the total sulfur in the melt, the partition coefficient varies from 0.017 to 0.075 for clinopyroxene, from 0.036 to 0.229 for plagioclase, and is a maximum of 0.001 for olivine and of 0.003 for orthopyroxene. The variation in the total sulfur partition coefficient positively correlates with cation-oxygen bond lengths in the crystals; the measured partition coefficients increase in the order: olivine $<$ orthopyroxene $<$ clinopyroxene $\leq$ amphibole and plagioclase. At high oxygen fugacities in hydrous experiments, the clinopyroxene/melt partition coefficients for total sulfur are only approximately one-third of those measured in low oxygen fugacity, anhydrous experiments. However when the partition coefficient is calculated as total sulfur in the crystal divided by $\mathrm{S}^{2-}$ in the melt, the clinopyroxene/melt partition coefficients for experiments with melts between $\sim 51$ and $66 \mathrm{wt} \%$ $\mathrm{SiO}_{2}$ can be described by a single mean value of $0.063 \pm 0.010$ ( $1 \sigma$ standard deviation about the mean). These two observations support the hypothesis that sulfur, as $\mathrm{S}^{2-}$, replaces oxygen in the crystal structure. The results of hydrous experiments at low oxygen fugacity and anhydrous experiments at high oxygen fugacity suggest that oxygen fugacity has a greater effect on sulfur partitioning than water. Although the total sulfur clinopyroxene-melt partition coefficients are affected by the $\mathrm{Mg} /(\mathrm{Mg}+\mathrm{Fe})$ ratio of the crystal, partition coefficients calculated using $\mathrm{S}^{2-}$ in the melt display no clear dependence upon the $\mathrm{Mg \#}$ of the clinopyroxene. Both the bulk and the $\mathrm{S}^{2-}$ partition coefficients appear unaffected by ${ }^{\mathrm{IV}} \mathrm{Al}$ in the clinopyroxene structure. No effect of anorthite content nor of iron concentration in the crystal was seen in the data for plagioclase-melt partitioning. The data obtained for orthopyroxene and olivine were too few to establish any trends. The partition coefficients of total sulfur and $\mathrm{S}^{2-}$ between the crystals studied and silicate melts are typically lower than those of fluorine, higher than those of carbon, and similar to those of chlorine and hydrogen. These sulfur partition coefficients can be combined with analyses of volatiles in nominally volatile-free minerals and previously published partition coefficients of $\mathrm{H}_{2} \mathrm{O}, \mathrm{C}, \mathrm{F}$, and $\mathrm{Cl}$ to constrain the concentration of the igneous quintet, the five major volatiles in magmatic systems.

Keywords: Clinopyroxene/melt sulfur partitioning, equilibrium melts, magmatic volatiles, synchrotron micro X-ray fluorescence

\section{INTRODU CTION}

Five volatiles (the igneous quintet), $\mathrm{H}_{2} \mathrm{O}, \mathrm{CO}_{2}, \mathrm{~F}, \mathrm{~S}$, and $\mathrm{Cl}$, dominate magmatic systems (e.g., Johnson et al. 1994; Symonds et al. 1994). They play multiple roles in the character of magma-

*E-mail: callesara84@gmail.com

$\dagger$ Orcid 0000-0003-0093-2759. tism, from influencing the explosivity of volcanic eruptions to driving local or global environmental upheavals through poisoning of the ecosystems by acid fallout and net cooling or heating of the troposphere (e.g., Robock 2013). Quantitative estimations of volatile concentrations in magmas come primarily from two types of samples: glassy rinds of submarine pillow lavas and melt inclusions trapped in phenocrysts. The former is quenched at a 
1 high enough hydrostatic pressure to prevent efficient degassing

2 of volatiles (except $\mathrm{C}$ and $\mathrm{H}$ ) from the melt, and the latter can be 3 trapped early enough in the magmatic system to be representative 4 of the pristine magmatic volatile concentrations. For instance, fo5 cusing on sulfur, dredged mid-ocean ridge basalt (MORB) glasses 6 were shown to contain 800-1300 ppm S (LeVoyer et al. 2014), 7 and melt inclusions enclosed in phenocrysts from \{\{auth: spell 8 out/define on first use \}\} OIBs up to $2100 \mathrm{ppm} \mathrm{S}$ (Azores, Rose9 Koga et al. 2017), from flood basalts up to 1300 ppm (Laki, Ice10 land; Hartley et al. 2017), and from arc magmas up to $2900 \mathrm{ppm}$ 11 (DeHoog et al. 2001; Johnson et al. 2009; Rusciutto et al. 2010). 12 These are concentrations typical of non-degassed melts $(>800$ 13 ppm; Wallace and Edmonds 2011 and references therein) and are 14 highly informative of the composition and oxidation state of the 15 mantle source of these magmas. However, data from such kinds 16 of samples pertain mostly to recent magmatic manifestations, 17 while working with subaerial and/or ancient eruptions, magmatic 18 volatiles quantification gets more challenging. Subaerial eruptions 19 tend to efficiently degas their volatile budget, e.g., a maximum of $20 \sim 150 \mathrm{ppm} \mathrm{S}$ was measured in subaerial matrix glasses (Wallace 21 and Edmonds 2011). Ancient volcanics tend to alter, making it 22 hard to find either fresh matrix glasses to analyze or preserved 23 melt inclusions. Valuable exceptions exist, with a precious few 24 melt inclusions successfully analyzed from flood basalts and 25 subvolcanic rocks from Large Igneous Provinces (e.g., Self et al. 26 2008, Deccan Traps; Sibik et al. 2015; Black et al. 2012, Siberian 27 Traps). In the absence of melt inclusions, volatile concentrations 28 in melts may be determined by the combination of the measure29 ment of volatile concentrations in natural minerals - typically at 30 the parts-per-million level in nominally volatile-free minerals 31 (NVFMs) such as olivine, orthopyroxene, clinopyroxene, and 32 plagioclase, with experimentally determined partition coefficients 33 between these crystals and melts.
To better use NVFMs as probes of melt volatile concentrations, additional measurements of partition coefficients are needed. In addition, the influence of magmatic variables such as melt composition (including water concentration), crystal structure and chemistry, and oxygen fugacity on partitioning needs to be examined, particularly for sulfur because of its change from an $\mathrm{S}^{2-}$ to an $\mathrm{S}^{6+}$ species in the melt with increasing oxygen fugacity (Wilke et al. 2011; Moretti and Baker 2011\{\{auth: not listed in Ref list please add or fix $\}\}$ ). Here we present the results obtained from piston-cylinder experiments designed to investigate the partitioning of sulfur between NVFMs and silicate melts as a function of these variables and compare these results to the partitioning behavior of the other volatiles constituting the igneous quintet.

\section{EXPERIMENTAL TECHNIQUES}

Experiments on basaltic compositions were performed with a powdered MORB and a powdered basalt (AN-31) of the Central Atlantic Magmatic Province (CAMP), collected from a lava flow in Morocco (Marzoli et al. 2019). Two intermediate-composition glasses were also used as starting materials; one andesitic glass (AT-29D) was made from a mixture of $95 \%$ Aleutian andesite and $5 \%$ diopside glass, added to facilitate clinopyroxene crystallization, and the other (AT-150) was a synthetic dacitic glass, whose composition was similar to a natural Aleutian rock. Starting samples AN-31, AT-29D, and AT-150 were enriched in sulfur through the addition of finely ground pyrrhotite and dry mixed in a horizontal rotary mill to homogenize them. Electron microprobe analyses of super-liquidus glasses of these starting materials are provided in Table 1 . The MORB contained approximately $800 \mathrm{ppm}$ sulfur, AN-31 approximately $900 \mathrm{ppm} \mathrm{S}$, and AT-29D and AT-150 both approximately $300 \mathrm{ppm}$ $\mathrm{S}$ (Table 1). Starting samples were ground by hand in a mortar to less than $50 \mu \mathrm{m}$ in size and stored in a drying oven at $\sim 120^{\circ} \mathrm{C}$ before experiments.

Low oxygen fugacity experiments were performed in graphite-lined platinum capsules. These double capsules minimize iron loss and create oxygen fugacity conditions approximately 1.5 to $2 \log$ units below the fayalite-quartz-magnetite buffer (FMQ), or FMQ-2 (e.g., Médard et al. 2008); at these conditions sulfur dissolved in the melt exists in a sulfide complex, $\mathrm{S}^{2-}$ (Wilke et al. 2011). Capsules for anhydrous experiments were loaded with starting materials $(\sim 10 \mathrm{mg})$ and dried in the oven before welding. Hydrous conditions were achieved by first adding liquid water and then the other starting materials before welding with the capsule immersed in water to keep the metal cool and prevent volatile loss during welding. All hydrous capsules were heated at $110^{\circ} \mathrm{C}$ for at least $2 \mathrm{~h}$ to test the weld, and any capsules whose weight changed either during welding or after heating were discarded.

High oxygen fugacity experiments were performed in $\mathrm{Au}_{75} \mathrm{Pd}_{25}$ capsules. These capsules mitigate iron loss and in our piston-cylinder assembly create oxygen fugacities approximately 1 to $2 \log$ units above FMQ, i.e., FMQ+1 to FMQ+2 (Dalpé and Baker 2000; Liu et al. 2007); at these $f_{\mathrm{O}_{2}}$ values much of the sulfur in the melt is present as a sulfate complex, $\mathrm{S}^{6+}$ (Wilke et al. 2011). The loading, drying, and heating procedures for these capsules were identical to those used for the graphite-in-Pt capsules.

Experiments were performed in a piston-cylinder using NaCl-pyrex-crushable alumina assemblies following the techniques of Baker (2004). Hydrous experimental capsules were surrounded by pyrophyllite or $\mathrm{Al}(\mathrm{OH})_{3}$ powder to reduce water loss (Freda et al. 2001). Experiments were simultaneously heated and pressurized to conditions above the liquidus and held at those conditions for 1 to $2 \mathrm{~h}$ to homogenize the melt and destroy any crystals in the starting material before cooling to subliquidus conditions at a rate of $1{ }^{\circ} \mathrm{C}$ per minute. Upon reaching the desired, sub-liquidus temperature the experiments were held at that temperature for a duration of approximately $24 \mathrm{~h}$, allowing crystal growth (Table 2). This duration has previously been shown sufficient for the andesite AT-29 and the MORB basalt to reach equilibrium conditions at anhydrous conditions and similar temperatures and pressures, even with residual melt compositions as rich in silica $\left(67 \mathrm{wt} \% \mathrm{SiO}_{2}\right)$ as those in this study (Baker and Eggler 1987; Baker 2008).

\section{ANALYTICAL TECHNIQUES}

Run-product phases were analyzed for major element concentrations on a JEOL 8900 electron microprobe (McGill University). We used an accelerating voltage of $15 \mathrm{kV}$, a beam current of $20 \mathrm{nA}$, and a beam diameter of $20 \mu \mathrm{m}$ for the glasses and $1 \mu \mathrm{m}$ for the crystals. We used $20 \mathrm{~s}$ counting time for the peaks of major elements and $200 \mathrm{~s}$ for $\mathrm{S}$ analyses of the quenched melts; background counting times

TABLE 1. Compositions of starting materials based upon microprobe analysis of super-liquidus glasses

\begin{tabular}{|c|c|c|c|c|}
\hline & MORB basalt & AN-31 CAMP tholeiite & AT-29D andesite & AT-150 dacite \\
\hline $\mathrm{SiO}_{2}$ (wt $\left.\%\right)$ & $49.5(0.70)$ & $50.2(0.18)$ & $55.99(0.58)$ & $63.22(0.26)$ \\
\hline $\mathrm{TiO}_{2}$ & $1.28(0.06)$ & $1.17(0.04)$ & $0.86(0.04)$ & $0.54(0.03)$ \\
\hline $\mathrm{Al}_{2} \mathrm{O}_{3}$ & $15.4(0.12)$ & $11.1(0.06)$ & $16.33(0.08)$ & $17.82(0.08)$ \\
\hline $\mathrm{FeO}^{*}$ & $9.37(0.27)$ & $11.4(0.17)$ & $7.86(0.37)$ & $4.81(0.09)$ \\
\hline $\mathrm{MnO}$ & $0.18(0.04)$ & $0.18(0.05)$ & $0.18(0.02)$ & $0.01(0.01)$ \\
\hline $\mathrm{MgO}$ & $8.89(0.11)$ & $12.8(0.12)$ & $4.00(0.16)$ & $1.73(0.03)$ \\
\hline $\mathrm{CaO}$ & $11.7(0.16)$ & $9.07(0.11)$ & $8.19(0.25)$ & $5.32(0.08)$ \\
\hline $\mathrm{Na}_{2} \mathrm{O}$ & $2.4(0.08)$ & $1.63(0.04)$ & $3.48(0.07)$ & $4.30(0.05)$ \\
\hline $\mathrm{K}_{2} \mathrm{O}$ & $0.1(0.01)$ & $0.66(0.03)$ & $1.94(0.07)$ & $1.76(0.03)$ \\
\hline $\mathrm{P}_{2} \mathrm{O}_{5}$ & $0.11(0.02)$ & $0.12(0.02)$ & $0.23(0.01)$ & $0.01(0.01)$ \\
\hline $\mathrm{S}(\mathrm{ppm})$ & 842 (39) & $911(36)$ & $366(67)$ & $263(23)$ \\
\hline Total & 98.93 & 98.33 & 99.07 & 99.46 \\
\hline
\end{tabular}

Note: Standard deviations in parentheses. 
TABLE 2. Experimental conditions and phases $\{\{\mathbf{A U : O K}$ ? $\}\}$

\begin{tabular}{|c|c|c|c|c|c|c|c|c|c|c|c|}
\hline Expt. & $\begin{array}{c}P \\
(\mathrm{GPa})\end{array}$ & $\begin{array}{c}T \\
\left({ }^{\circ} \mathrm{C}\right)^{\mathrm{a}} \\
\end{array}$ & $\begin{array}{c}\text { Time } \\
h^{\mathrm{b}} \\
\end{array}$ & $\begin{array}{c}f_{\mathrm{O}_{2}} \\
\Delta \mathrm{FMQ}^{\mathrm{c}} \\
\end{array}$ & $\begin{array}{c}\mathrm{H}_{2} \mathrm{O} \\
(w t \%) \\
\end{array}$ & Phase & $n^{\mathrm{d}}$ & $\begin{array}{c}\mathrm{S} \\
(\mathrm{ppm})\end{array}$ & $\mathrm{S}^{6+} / S_{\text {tot }}{ }^{e}$ & $\begin{array}{c}D \\
(\mathrm{~S} \text { tot })^{\mathrm{f}} \\
\end{array}$ & $\begin{array}{c}D \\
\left(S^{2-}\right)^{g} \\
\end{array}$ \\
\hline \multicolumn{12}{|c|}{ Starting material MORB - basaltic glass } \\
\hline \multirow[t]{3}{*}{ DRB2012-36 } & 1.0 & $1350 / 1240$ & $2 / 20.1$ & -2 & n.a. ${ }^{h}$ & glass & 12 & $1032(84)$ & 0 & & \\
\hline & & & & & & $\mathrm{Cpx}$ & [8] & $29(7)$ & & 0.028 & 0.028 \\
\hline & & & & & & $\mathrm{PI}$ & [1] & $37(1)$ & & 0.036 & 0.036 \\
\hline \multirow[t]{2}{*}{ DRB2012-38 } & 1.2 & $1350 / 1240$ & $2 / 20$ & -2 & n.a. & glass & 12 & $1090(27)$ & 0 & & \\
\hline & & & & & & $\mathrm{Cpx}$ & [8] & $25(11)$ & & 0.023 & 0.023 \\
\hline \multirow[t]{2}{*}{ CS2014-13 } & 1.0 & $1350 / 1240$ & $2 / 24$ & 1.8 & n.a. & glass & 10 & $917(36)$ & 0.73 & & \\
\hline & & & & & & Cpx & [4] & $16(13)$ & & 0.017 & 0.065 \\
\hline \multirow[t]{3}{*}{ DRB2015-1 } & 1.0 & $1150 / 1060$ & $2 / 24$ & 1.5 & $7.6(0.9)$ & glass & 18 [3] & $1156(62)$ & 0.63 & & \\
\hline & & & & & & $\mathrm{Cpx}$ & [5] & $21(7)$ & & 0.018 & 0.049 \\
\hline & \multicolumn{11}{|c|}{ Starting material AN-31 - basaltic glass from CAMP tholeiite } \\
\hline \multirow[t]{3}{*}{ DRB2012-29 } & 0.8 & $1350 / 1240$ & $2 / 24$ & -2 & n.a. & glass & 18 & $933(28)$ & 0 & & \\
\hline & & & & & & Opx & [9] & $3(2)$ & & 0.003 & 0.003 \\
\hline & & & & & & $\mathrm{Ol}$ & [2] & $1(0.2)$ & & 0.001 & 0.001 \\
\hline \multirow[t]{2}{*}{ DRB2012-35 } & 1.0 & $1350 / 1240$ & $2 / 20.1$ & -2 & n.a. & glass & 12 & $1116(22)$ & 0 & & \\
\hline & & & & & & Cpx & [6] & $29(9)$ & & 0.026 & 0.026 \\
\hline \multirow[t]{2}{*}{ DRB2012-37 } & 1.2 & $1350 / 1240$ & $2 / 20$ & -2 & n.a. & glass & 12 & $1096(19)$ & 0 & & \\
\hline & & & & & & $\mathrm{Cpx}$ & [8] & $31(9)$ & & 0.028 & 0.028 \\
\hline \multirow[t]{3}{*}{ CS2014-14 } & 1.0 & $1350 / 1240$ & $2 / 24$ & 1.7 & n.a. & glass & 12 & $1037(42)$ & 0.73 & & \\
\hline & & & & & & Opx & [3] & $2(1)$ & & 0.002 & 0.007 \\
\hline & & & & Starting & rial AT-29D & desitic & & & & & \\
\hline \multirow[t]{3}{*}{ CS2014-9 } & 0.8 & $1300 / 1160$ & $2 / 24$ & -2 & n.a. & glass & 10 & $571(60)$ & 0 & & \\
\hline & & & & & & Cpx & [4] & $33(7)$ & & 0.058 & 0.058 \\
\hline & & & & & & $\mathrm{PI}$ & [1] & 57 (8) & & 0.100 & 0.100 \\
\hline \multirow[t]{3}{*}{ CS2014-5 } & 0.8 & $1300 / 1140$ & $1 / 24$ & -2 & n.a. & glass & 11 & 717 (145) & 0 & & \\
\hline & & & & & & $\mathrm{Cpx}$ & [3] & $54(22)$ & & 0.075 & 0.075 \\
\hline & & & & & & $\mathrm{Pl}$ & [4] & $47(13)$ & & 0.065 & 0.065 \\
\hline \multirow[t]{3}{*}{ CS2014-3 } & 0.8 & 1300/1118 & $1 / 24$ & -2 & n.a. & glass & 22 & 551 (141) & 0 & & \\
\hline & & & & & & Cpx & [2] & $38(11)$ & & 0.069 & 0.069 \\
\hline & & & & & & $\mathrm{Pl}$ & [4] & $44(20)$ & & 0.080 & 0.080 \\
\hline \multirow[t]{3}{*}{ CS2014-30 } & 0.8 & $1150 / 1000$ & $2 / 24$ & -2 & $1.1(0.3)$ & glass & 15 & $689(181)$ & 0 & & \\
\hline & & & & & & $\mathrm{PI}$ & [2] & $61(36)$ & & 0.089 & 0.089 \\
\hline & & & & & & Amp & [5] & $87(58)$ & & 0.127 & 0.127 \\
\hline \multirow[t]{2}{*}{ DRB2015-2 } & 1.0 & $1150 / 1060$ & $2 / 24$ & 1.5 & $6.3(0.3)$ & glass & 19 & 742 (55) & 0.62 & & \\
\hline & & & & & & Cpx & [6] & $13(7)$ & & 0.018 & 0.046 \\
\hline \multirow[t]{3}{*}{ CS2014-19 } & 0.8 & $1150 / 1000$ & $2 / 24$ & 0.9 & $11.2(0.5)$ & glass & 14 & $580(80)$ & 0.33 & & \\
\hline & & & & & & Cpx & [4] & $25(12)$ & & 0.043 & 0.064 \\
\hline & & & & Startin & erial AT-15 & acitic $\mathbf{g}$ & & & & & \\
\hline \multirow[t]{3}{*}{ CS2014-31 } & 0.8 & $1150 / 1000$ & $2 / 24$ & -2 & $1.1(0.3)$ & glass & 10 & 292 (35) & 0 & & \\
\hline & & & & & & $\mathrm{Cpx}$ & [2] & $21(8)$ & & 0.072 & 0.072 \\
\hline & & & & & & $\mathrm{PI}$ & [4] & $67(20)$ & & 0.229 & 0.229 \\
\hline \multirow[t]{4}{*}{ CS2014-20 } & 0.8 & $1150 / 1000$ & $2 / 24$ & 1.1 & $5.7(0.8)$ & glass & 10 & 237 (44) & 0.41 & & \\
\hline & & & & & & $\mathrm{Cpx}$ & [1] & $9(1)$ & & 0.038 & 0.064 \\
\hline & & & & & & $\mathrm{Pl}$ & [2] & $93(10)$ & & 0.393 & 0.666 \\
\hline & & & & & & Amp & [2] & $29(14)$ & & 0.123 & 0.208 \\
\hline
\end{tabular}

Notes: Water concentration (measured by Raman spectroscopy) and sulfur concentration and oxidation state (measured by electron microprobe) in the glass phase 38 are reported. Sulfur concentration in the crystals was measured by SXRF. Partition coefficients are reported for total S and for $\mathrm{S}^{2-}$. Standard deviation values are in 39 parentheses. Where only a single analysis is available, the uncertainty is the analytical uncertainty measured through peak counting statistics as discussed in the 39
"Analytical Analytical Techniques" section (i.e., $14 \%$ relative for S concentrations $>6$ ppm). Analytical Techniques" section (i.e., $14 \%$ relative for $S$ concentrations $>6$ ppm)

${ }^{\mathrm{b}}$ The duration of the high temperature step followed by the duration of the low temperature step.

'The oxgen fugacity of the experiment; see text for discussion.

${ }^{d}$ Number of analyses by electon microprobe (for glass), and in brackets by SXRF (for crystals and one experiment glass).

e Fraction of $\mathrm{S}^{6+}$ in the glass determined by peak shift of the sulfur X-ray measured on the electron microprobe.

${ }^{f}$ Crystal-melt partition coefficient of sulfur determined by dividing the sulfur measured in the crystal by the total sulfur measured in the glass.

${ }^{g}$ Crystal-melt partition coefficient of sulfur determined by dividing the sulfur measured in the crystal by the $\mathrm{S}^{2-}$ measured in the glass.

${ }^{\mathrm{h}} \mathrm{n}$.a. = not analyzed; $\mathrm{Ol}=$ olivine; $\mathrm{Cpx}=$ clinopyroxene; $\mathrm{Opx}=$ orthopyroxene; $\mathrm{PI}=$ plagioclase; $\mathrm{Amp}=$ amphibole.

were all one-half of those on the peaks. The lower detection limit of S in glasses was approximately $100 \mathrm{ppm}$. Synthetic pyrrhotite was used as the sulfur standard for analyses of experiments at low oxygen fugacity, whereas barite was used for experiments at high oxygen fugacity. The standards used for glass analyses were a basaltic glass, VG-A99 (Jarosewich et al. 1980), for $\mathrm{Na}, \mathrm{Al}, \mathrm{Fe}, \mathrm{Si}, \mathrm{Mg}, \mathrm{Ca}$, and $\mathrm{Ti}$; a rhyolitic glass for $\mathrm{K}$; a spessartine for $\mathrm{Mn}$; and a fluorapatite for P. Basaltic glass standards VG-2 (1410 ppm S) and VG-A99 (125 ppm S) were repeatedly analyzed to ensure the accuracy of our analyses (cf. Liu et al. 2007; Fortin et al. 2015). The standards used for mafic crystal analyses were diopside for $\mathrm{Ca}$ and $\mathrm{Mg}$ and olivine for $\mathrm{Fe}$; feldspars were used as $\mathrm{Na}, \mathrm{K}$, and $\mathrm{Al}$ standards for the analyses of the plagioclase crystals formed in the experiments. The standards for all other elements were the same as those used for glass analyses.

The oxygen fugacity in all high oxygen fugacity experiments was determined by the sulfur peak shift method pioneered by Carroll and Rutherford (1988). The 48 wavelength of the sulfur peak in the glass of each high oxygen fugacity experiment 49 was found using the electron microprobe by scanning the peak of 20 different 50 spots in the glass and then summing the scans to increase the peak-to-background 51 ratio. A $10 \mu \mathrm{m}$ diameter beam with a $15 \mathrm{kV}$ potential and $20 \mathrm{nA}$ current was used 52 to minimize possible sulfur oxidation during analysis. This measured peak posi- 53 tion was then compared to the sulfur peak positions measured in sphalerite, the 53 sulfide standard, and barite, the sulfate standard, to determine the fraction of sulfur 54 dissolved as sulfate in the melt (Carroll and Rutherford 1988). From this sulfate 55 fraction, the log of the oxygen fugacity relative to the FMQ buffer was calculated 56 following Wilke et al. (2011).

Water was measured in the run-product glasses of all hydrous experiments by 57 Raman spectroscopy (see Supplementary ${ }^{1}$ Fig. S1), following Fortin et al. (2015) 58 


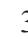

TABLE 3. Electron microprobe analyses of the glass and crystal phases obtained from the experiments

\begin{tabular}{|c|c|c|c|c|c|c|c|c|c|c|}
\hline & Expt. & Phase & $n^{\mathrm{a}}$ & $\mathrm{SIO}_{2}$ & $\mathrm{TiO}_{2}$ & $\mathrm{Al}_{2} \mathrm{O}_{3}$ & $\mathrm{FeO}^{*}$ & $\mathrm{MnO}$ & $\mathrm{MgO}$ & $\mathrm{CaO}$ \\
\hline \multirow{9}{*}{$\begin{array}{l}\text { Starting } \\
\text { material MORB }\end{array}$} & \multirow[t]{3}{*}{ DRB2012-36 } & glass & 12 & $48.98(0.3)$ & $1.48(0.11)$ & $16.48(0.12)$ & $10.71(0.23)$ & $0.19(0.02)$ & $7.18(0.09)$ & $10.38(0.07)$ \\
\hline & & Cpx & 9 & $52.07(1.41)$ & $0.42(0.17)$ & $5.55(2.06)$ & $7.25(1)$. & $0.19(0.04)$ & $19.78(2.46)$ & $13.68(2.56)$ \\
\hline & & & 1 & $53.44(0.53)^{b}$ & n.a.c & $28.81(0.29)$ & $0.33(0.03)$ & n.a. & $0.16(0.02)$ & $12.14(0.12)$ \\
\hline & \multirow[t]{2}{*}{ DRB2012-38 } & glass & 12 & $49.33(0.14)$ & $1.53(0.05)$ & $17.21(0.11)$ & $10.54(0.12)$ & $0.17(0.03)$ & $6.42(0.06)$ & $9.80(0.05)$ \\
\hline & & Cpx & 10 & $50.18(0.37)$ & $0.61(0.11)$ & $8.36(0.53)$ & $6.95(0.59)$ & $0.18(0.03)$ & $17.10(0.57)$ & $15.27(0.93)$ \\
\hline & \multirow[t]{2}{*}{ CS2014-13 } & glass & 10 & $50.70(0.22)$ & $1.39(0.04)$ & $16.57(0.24)$ & $8.54(0.16)$ & $0.18(0.02)$ & $8.46(0.2)$ & $10.93(0.08)$ \\
\hline & & $\mathrm{Cpx}$ & 28 & $49.27(0.72)$ & $0.63(0.18)$ & $8.78(1.39)$ & $6.90(0.42)$ & $0.18(0.03)$ & $15.93(1.26)$ & $17.01(1.04)$ \\
\hline & \multirow[t]{2}{*}{ DRB2015-1 } & glass & 18 & $51.88(0.25)$ & $0.72(0.03)$ & $18.23(0.12)$ & $4.03(0.12)$ & $0.16(0.03)$ & $5.71(0.15)$ & $8.35(0.17)$ \\
\hline & & Cpx & 52 & $48.04(2.09)$ & $0.68(0.29)$ & $6.58(1.77)$ & $7.46(1.09)$ & n.a. & $15.76(1.77)$ & $20.17(0.86)$ \\
\hline \multirow{9}{*}{$\begin{array}{l}\text { Starting } \\
\text { material AN-31 }\end{array}$} & \multirow[t]{3}{*}{ DRB2012-29 } & glass & 18 & $50.83(0.48)$ & $1.29(0.07)$ & $13.28(0.16)$ & $10.40(0.21)$ & $0.18(0.05)$ & $8.80(0.13)$ & $10.50(0.18)$ \\
\hline & & Opx & 42 & $55.52(0.55)$ & $0.18(0.06)$ & $2.04(0.59)$ & $8.65(0.48)$ & $0.17(0.03)$ & $30.89(1.34)$ & $2.07(0.53)$ \\
\hline & & Ol & 19 & $39.66(0.23)$ & $0.01(0.02)$ & $0.03(0.01)$ & $14.53(0.44)$ & $0.19(0.02)$ & $45.35(0.48)$ & $0.24(0.02)$ \\
\hline & \multirow[t]{2}{*}{ DRB2012-35 } & glass & 12 & $48.85(0.24)$ & $1.52(0.03)$ & $14.21(0.1)$ & $10.84(0.12)$ & $0.18(0.03)$ & $8.04(0.07)$ & $10.35(0.05)$ \\
\hline & & $\mathrm{Cpx}$ & 10 & $55.31(0.41)$ & $0.18(0.05)$ & $2.22(0.28)$ & $9.82(0.39)$ & $0.18(0.03)$ & $28.91(1.5)$ & $3.33(1.54)$ \\
\hline & \multirow[t]{2}{*}{ DRB2012-37 } & glass & 12 & $49.10(0.23)$ & $1.40(0.04)$ & $14.14(0.1)$ & $11.11(0.12)$ & $0.17(0.04)$ & $7.92(0.08)$ & $10.09(0.06)$ \\
\hline & & Cpx & 10 & $54.91(0.29)$ & $0.16(0.03)$ & $2.60(0.31)$ & $10.10(0.52)$ & $0.20(0.02)$ & $28.72(1.2)$ & $3.20(1.26)$ \\
\hline & \multirow[t]{2}{*}{ CS2014-14 } & glass & 12 & $50.22(0.24)$ & $1.25(0.03)$ & $12.76(0.15)$ & $10.62(0.18)$ & $0.18(0.03)$ & $10.00(0.25)$ & $10.02(0.19)$ \\
\hline & & Opx & 31 & $54.32(1.13)$ & $0.14(0.05)$ & $3.47(0.56)$ & $7.45(0.54)$ & $0.19(0.03)$ & $31.01(0.73)$ & $1.96(0.25)$ \\
\hline \multirow{16}{*}{$\begin{array}{l}\text { Starting } \\
\text { material AT-29D }\end{array}$} & \multirow[t]{3}{*}{ CS2014-9 } & glass & 10 & $57.67(0.36)$ & $1.23(0.06)$ & $15.27(0.13)$ & $9.78(0.25)$ & $0.20(0.03)$ & $2.77(0.09)$ & $5.95(0.12)$ \\
\hline & & Cpx & 16 & $51.23(0.9)$ & $0.50(0.15)$ & $3.68(0.96)$ & $12.55(1.53)$ & $0.40(0.05)$ & $16.76(1.53)$ & $13.54(2.74)$ \\
\hline & & $\mathrm{Pl}$ & 20 & $58.06(0.47)$ & n.a. & $25.82(0.26)$ & $0.44(0.07)$ & n.a. & $0.10(0.02)$ & $8.57(0.33)$ \\
\hline & \multirow[t]{3}{*}{ CS2014-5 } & glass & 11 & $56.67(0.29)$ & $1.41(0.04)$ & $14.55(0.14)$ & $10.55(0.33)$ & $0.20(0.02)$ & $2.69(0.07)$ & $5.90(0.12)$ \\
\hline & & Cpx & 18 & $51.53(0.5)$ & $0.55(0.13)$ & $3.19(0.76)$ & $12.69(1.51)$ & $0.40(0.05)$ & $16.91(1.27)$ & $13.57(2.39)$ \\
\hline & & $\mathrm{PI}$ & 22 & $57.90(0.32)$ & n.a. & $26.09(0.25)$ & $0.47(0.11)$ & n.a. & $0.12(0.04)$ & $8.86(0.21)$ \\
\hline & \multirow[t]{3}{*}{ CS2014-3 } & glass & 22 & $56.28(0.3)$ & $1.07(0.14)$ & $15.35(0.47)$ & $9.34(0.45)$ & $0.20(0.03)$ & $3.53(0.26)$ & $6.94(0.34)$ \\
\hline & & Cpx & 19 & $51.67(0.42)$ & $0.62(0.12)$ & $3.89(0.67)$ & $10.06(1.28)$ & $0.33(0.05)$ & 16.65 (1.19) & $16.07(2.09)$ \\
\hline & & $\mathrm{PI}$ & 13 & $57.34(0.67)$ & n.a. & $26.20(0.35)$ & $0.41(0.14)$ & n.a. & $0.13(0.04)$ & $9.19(0.29)$ \\
\hline & \multirow{3}{*}{ CS2014-30 } & glass & 15 & 59.49 (1.07) & $2.04(0.18)$ & $13.59(0.35)$ & $10.32(1.02)$ & $0.18(0.04)$ & $1.05(0.08)$ & $3.93(0.32)$ \\
\hline & & $\mathrm{PI}$ & 17 & $58.55(0.83)$ & n.a. & $25.59(0.68)$ & $0.46(0.07)$ & n.a. & $0.05(0.01)$ & $8.13(0.7)$ \\
\hline & & Amp & 5 & $55.67(0.91)$ & $1.22(0.51)$ & $10.50(3.71)$ & $11.70(3.71)$ & $0.32(0.08)$ & $6.35(1.87)$ & 8.36 (2.42) \\
\hline & \multirow[t]{2}{*}{ DRB2015-2 } & glass & 19 & $55.76(0.43)$ & $0.54(0.04)$ & $16.39(0.15)$ & $3.44(0.09)$ & $0.16(0.02)$ & $2.92(0.06)$ & $6.57(0.09)$ \\
\hline & & Cpx & 29 & $44.38(0.44)$ & $0.85(0.14)$ & $8.62(0.36)$ & $10.81(0.47)$ & n.a. & $11.58(0.36)$ & $21.78(0.15)$ \\
\hline & \multirow[t]{2}{*}{ CS2014-19 } & glass & 14 & $57.84(0.33)$ & $0.57(0.05)$ & $17.13(0.14)$ & $3.37(0.12)$ & $0.14(0.02)$ & $2.44(0.1)$ & $5.67(0.12)$ \\
\hline & & Cpx & 17 & $44.94(1.08)$ & $1.13(0.21)$ & $8.88(0.52)$ & $10.03(1.17)$ & $0.25(0.03)$ & $11.50(0.71)$ & $21.36(0.26)$ \\
\hline \multirow{8}{*}{$\begin{array}{l}\text { Starting } \\
\text { material AT-150 }\end{array}$} & \multirow[t]{3}{*}{ CS2014-31 } & glass & 10 & $66.11(0.8)$ & $0.90(0.07)$ & $13.74(0.58)$ & $6.66(0.43)$ & n.a. & $1.00(0.19)$ & $3.43(0.23)$ \\
\hline & & Cpx & 10 & $52.64(0.39)$ & $0.32(0.05)$ & $2.27(0.4)$ & $20.16(1.32)$ & n.a. & $20.08(1.09)$ & $4.15(0.42)$ \\
\hline & & $\mathrm{Pl}$ & 25 & $58.99(1.14)$ & n.a. & $25.74(0.72)$ & $0.41(0.14)$ & n.a. & $0.08(0.02)$ & $8.48(0.57)$ \\
\hline & \multirow[t]{5}{*}{ CS2014-20 } & glass & 10 & $61.34(1.24)$ & $0.46(0.07)$ & $16.78(0.7)$ & $3.27(0.27)$ & n.a. & $1.44(0.14)$ & $4.47(0.34)$ \\
\hline & & Cpx & 4 & 45.34 (1.39) & $0.66(0.14)$ & $10.03(1.51)$ & $9.69(0.67)$ & n.a. & $10.61(0.71)$ & $21.84(0.08)$ \\
\hline & & $\mathrm{Pl}$ & 4 & $57.61(0.39)$ & n.a. & $25.87(0.11)$ & $0.90(0.09)$ & n.a. & $0.07(0.01)$ & $9.05(0.09)$ \\
\hline & & Amp & 3 & $55.23(2.87)$ & $0.51(0.18)$ & $14.14(1.3)$ & $5.79(1.61)$ & n.a. & $5.39(1.71)$ & $13.30(2.59)$ \\
\hline & & $\mathrm{Opq}$ & 1 & 0.00 & $12.14(0.12)$ & $2.14(0.02)$ & $73.97(0.74)$ & n.a. & $1.42(0.01)$ & $0.05(0.01)$ \\
\hline
\end{tabular}

Notes: Totals for the glass phases do not include $\mathrm{SO}_{3} \mathrm{wt} \%$, nor $\mathrm{H}_{2} \mathrm{O}$ and $\mathrm{Cl}$ wt\% (where analyzed).

${ }^{a}$ Number of analyses by electon microprobe for major and minor elements.

${ }^{b}$ Where only a single analysis is available, the uncertaintly is the analytical uncertainty from counting statistics.

${ }^{c}$ n.a. = not analyzed; $\mathrm{Ol}=$ olivine; $\mathrm{Cpx}=$ clinopyroxene; Opx = orthopyroxene; $\mathrm{PI}=$ plagioclase; $\mathrm{Amp}=$ amphibole; Opq = opaque phase.

using as standards a set of andesitic and basaltic glasses previously analyzed by ion microprobe (Fortin et al. 2015).

Sulfur in the crystals was measured by synchrotron X-ray microfluorescence (SXRF) on beamline I18 at the Diamond Light Source synchrotron, U.K. (Mosselmans et al. 2009). Synchrotron X-ray fluorescence analyses of silicon and sulfur concentrations in the crystals were performed in a helium atmosphere using a $3 \mathrm{keV}$ beam focused to $6 \times 6 \mu \mathrm{m}$ by a pair of Kirkpatrick-Baez mirrors, and the fluorescence spectra of the samples were measured with a Vortex silicon drift detector. Sulfur concentrations were determined from the spectra by PyMca (Solé et al. 2007) using the silicon concentration of the minerals as the internal reference for quantification.

The SXRF analytical technique for sulfur was tested by analysis of two in-house clinopyroxene crystal standards. The crystals were gem-quality DeKalb diopside (USNM \#R18685) and F-14 clinopyroxene from Frosty Peak, Alaska, U.S.A. (collected by D.R.B.). Bulk analyses of these crystals for sulfur were made at the Saskatchewan Research Council Geoanalytical Laboratories using a LECO induction furnace carbon and sulfur analyzer (https://www.src.sk.ca/labs/geoanalyticallaboratories). Three different aliquots of DeKalb diopside yielded a mean sulfur concentration of $32 \pm 15 \mathrm{ppm}$ (1 St.dev.), and one aliquot of the F-14 clinopyroxene contained $32 \mathrm{ppm}$ sulfur (Supplementary ${ }^{1}$ Table S1). Aliquots of international standards BHVO-2, JP-1, and JB-2 were analyzed in the same analytical batch, and the results reproduced the published recommended values for these standards (Erdman et al. 2014). Eight SXRF analyses of DeKalb diopside crystals produced a mean sulfur concentration of $32 \pm 18 \mathrm{ppm}$ and six analyses of F-14 clinopyroxene crystals yielded a concentration of $22 \pm 9 \mathrm{ppm}$ sulfur. The agreement of bulk sulfur analyses and the average of the SXRF analyses is within $1 \sigma$ uncertainty for DeKalb and just outside the $1 \sigma$ uncertainty for F-14, although both crystals display hetero- geneity in sulfur concentrations. Analyses of the same crystals were attempted by ion microprobe (CAMECA ims 1280 at Nordsim Laboratory, Stockholm Natural History Museum, Sweden) using glass standards for calibration and yielded sulfur concentrations in DeKalb and F-14 less than $1 \mathrm{ppm}$. Because of the significant difference between the bulk sulfur analyses and those obtained by ion microprobe, we did not use the latter in this study. We suggest that the difference between ion microprobe and SXRF analyses may be due to inadequate standards for ion probe sulfur analysis in mafic crystals.

We calculated a detection limit of approximately $1 \mathrm{ppm}$ for our SXRF analyses by two different methods (p. 446, Goldstein et al. 2003; Rousseau 2001). Based upon a relative uncertainty of $10 \%$ in our electron microprobe analyses as well as $10 \%$ uncertainty seen in our peak fitting areas, we calculate through error propagation (Rousseau 2001) an analytical uncertainty of 14\% relative for samples with $6 \mathrm{ppm}$ and greater. At 2 ppm sulfur, the uncertainty in the peak fitting areas reaches $37 \%$, and the analytical uncertainty becomes $38 \%$ relative.

\section{RESULTS}

The experimental conditions and the analyses of the run product phases are presented in Tables 2 and 3. Experimental conditions were chosen for the crystallization of clinopyroxene, but plagioclase, low-calcium pyroxene, olivine, amphibole, and opaque phases were also present in selected experiments. Iron sulfide phases, either quenched from an immiscible liquid or present as a stable sulfide crystal, were observed in three experiments 
TABLE 3.-EXTENDED

\begin{tabular}{|c|c|c|c|c|c|c|c|}
\hline & Expt. & Phase & $n^{\mathrm{a}}$ & $\mathrm{Na}_{2} \mathrm{O}$ & $\mathrm{K}_{2} \mathrm{O}$ & $\mathrm{P}_{2} \mathrm{O}_{5}$ & Total \\
\hline \multirow{9}{*}{$\begin{array}{l}\text { Starting } \\
\text { material } \\
\text { MORB }\end{array}$} & \multirow[t]{3}{*}{ DRB2012-36 } & glass & 12 & $2.92(0.06)$ & $0.13(0.01)$ & $0.12(0.07)$ & 98.57 \\
\hline & & Cpx & 9 & $0.41(0.1)$ & $0.02(0.01)$ & $0.04(0.03)$ & 99.40 \\
\hline & & $\mathrm{PI}$ & 1 & $4.29(0.43)$ & $0.05(0.01)$ & n.a. & 99.35 \\
\hline & \multirow[t]{2}{*}{ DRB2012-38 } & glass & 12 & $3.13(0.02)$ & $0.13(0.01)$ & $0.16(0.05)$ & 98.42 \\
\hline & & Cpx & 10 & $0.62(0.07)$ & $0.02(0.01)$ & $0.06(0.08)$ & 99.34 \\
\hline & \multirow[t]{2}{*}{ CS2014-13 } & glass & 10 & $2.65(0.08)$ & $0.11(0.01)$ & $0.13(0.01)$ & 99.65 \\
\hline & & Cpx & 28 & $0.63(0.15)$ & $0.02(0.02)$ & n.a. & 99.35 \\
\hline & \multirow[t]{2}{*}{ DRB2015-1 } & glass & 18 & $3.06(0.09)$ & $0.13(0.01)$ & $0.15(0.02)$ & 92.40 \\
\hline & & Cpx & 52 & $0.50(0.06)$ & $0.02(0.01)$ & n.a. & 99.21 \\
\hline \multirow{9}{*}{$\begin{array}{l}\text { Starting } \\
\text { material } \\
\text { AN-31 }\end{array}$} & \multirow[t]{3}{*}{ DRB2012-29 } & glass & 18 & $1.98(0.05)$ & $0.81(0.03)$ & $0.15(0.02)$ & 98.22 \\
\hline & & Opx & 42 & $0.05(0.06)$ & $0.02(0.03)$ & n.a. & 99.60 \\
\hline & & Ol & 19 & n.a. & $0.02(0.01)$ & $0.04(0.02)$ & 100.08 \\
\hline & \multirow[t]{2}{*}{ DRB2012-35 } & glass & 12 & $2.25(0.04)$ & $0.91(0.02)$ & $0.15(0.07)$ & 97.31 \\
\hline & & Cpx & 10 & $0.09(0.04)$ & $0.02(0.01)$ & $0.05(0.06)$ & 100.11 \\
\hline & \multirow[t]{2}{*}{ DRB2012-37 } & glass & 12 & $2.28(0.03)$ & $0.94(0.02)$ & $0.16(0.08)$ & 97.31 \\
\hline & & Cpx & 10 & $0.09(0.04)$ & $0.02(0.01)$ & $0.06(0.04)$ & 100.07 \\
\hline & \multirow[t]{2}{*}{ CS2014-14 } & glass & 12 & $1.94(0.03)$ & $0.78(0.02)$ & $0.15(0.01)$ & 97.91 \\
\hline & & Opx & 31 & $0.06(0.02)$ & $0.02(0.01)$ & n.a. & 98.62 \\
\hline \multirow{16}{*}{$\begin{array}{l}\text { Starting } \\
\text { material } \\
\text { AT-29D }\end{array}$} & \multirow[t]{3}{*}{ CS2014-9 } & glass & 10 & $3.42(0.04)$ & $2.80(0.06)$ & $0.36(0.02)$ & 99.45 \\
\hline & & Cpx & 16 & $0.38(0.1)$ & $0.03(0.01)$ & n.a. & 99.07 \\
\hline & & $\mathrm{PI}$ & 20 & $5.74(0.12)$ & $1.16(0.13)$ & n.a. & 99.90 \\
\hline & \multirow[t]{3}{*}{ CS2014-5 } & glass & 11 & $3.39(0.06)$ & $2.92(0.04)$ & $0.41(0.03)$ & 98.73 \\
\hline & & Cpx & 18 & $0.32(0.08)$ & $0.03(0.01)$ & n.a. & 99.19 \\
\hline & & PI & 22 & $5.73(0.08)$ & $1.01(0.09)$ & n.a. & 100.18 \\
\hline & \multirow[t]{3}{*}{ CS2014-3 } & glass & 22 & $3.42(0.07)$ & $2.43(0.14)$ & $0.29(0.05)$ & 98.85 \\
\hline & & Cpx & 19 & $0.38(0.06)$ & $0.03(0.03)$ & n.a. & 99.70 \\
\hline & & $\mathrm{PI}$ & 13 & $5.56(0.14)$ & $0.88(0.1)$ & n.a. & 99.71 \\
\hline & \multirow[t]{3}{*}{ CS2014-30 } & glass & 15 & $3.29(0.1)$ & $4.24(0.21)$ & $0.67(0.06)$ & 98.79 \\
\hline & & $\mathrm{PI}$ & 17 & $5.99(0.23)$ & $1.19(0.33)$ & n.a. & 99.95 \\
\hline & & Amp & 5 & $1.96(0.79)$ & $2.04(0.77)$ & n.a. & 98.11 \\
\hline & \multirow[t]{2}{*}{ DRB2015-2 } & glass & 19 & $3.54(0.06)$ & $2.13(0.04)$ & $0.25(0.02)$ & 91.72 \\
\hline & & Cpx & 29 & $0.79(0.04)$ & $0.02(0.01)$ & n.a. & 98.83 \\
\hline & \multirow[t]{2}{*}{ CS2014-19 } & glass & 14 & $3.20(0.1)$ & $2.05(0.06)$ & $0.25(0.01)$ & 92.68 \\
\hline & & Cpx & 17 & $0.59(0.04)$ & $0.03(0.03)$ & n.a. & 98.70 \\
\hline \multirow{8}{*}{$\begin{array}{l}\text { Starting } \\
\text { material } \\
\text { AT-150 }\end{array}$} & \multirow[t]{3}{*}{ CS2014-31 } & glass & 10 & $3.65(0.1)$ & $2.69(0.1)$ & n.a. & 98.19 \\
\hline & & Cpx & 10 & $0.10(0.05)$ & $0.04(0.04)$ & n.a. & 99.78 \\
\hline & & $\mathrm{Pl}$ & 25 & $6.15(0.25)$ & $0.49(0.11)$ & n.a. & 100.33 \\
\hline & \multirow[t]{5}{*}{ CS2014-20 } & glass & 10 & $4.62(0.08)$ & $1.64(0.03)$ & n.a. & 94.04 \\
\hline & & Cpx & 4 & $0.82(0.04)$ & $0.02(0.01)$ & n.a. & 99.02 \\
\hline & & $\mathrm{PI}$ & 4 & $6.09(0.12)$ & $0.29(0.01)$ & n.a. & 99.87 \\
\hline & & Amp & 3 & $1.90(0.22)$ & $0.97(0.37)$ & n.a. & 97.23 \\
\hline & & Opq & 1 & 0.00 & $0.031(0.01)$ & n.a. & 89.74 \\
\hline
\end{tabular}

(CS2014-3, -5, and -30), but in each experiment the modal proportion of sulfides was less than 5\%. The typical morphologies of the crystals in low oxygen-fugacity experiments with basaltic compositions were euhedral to subhedral (Fig. 1a), whereas crystals in experiments with basaltic compositions at high oxygen fugacity and experiments with andesitic and dacitic bulk compositions were typically subhedral to anhedral (Fig. 1b). Most crystals were approximately $100 \mu \mathrm{m}$ in their minimum dimension; however, some were as low as $25 \mu \mathrm{m}$ and some as high as $400 \mu \mathrm{m}$ across. All the crystals were significantly larger than the beam sizes of all applied analytical techniques $(6-2 \mu \mathrm{m})$. The smallest crystals allowed for only one analysis each, while several analyses (for instance at the core and at the rim) were performed on the largest crystals. In all run products, the rims (within $10 \mu \mathrm{m}$ of the melt) of the most euhedral crystals were used for the measurement of major element and sulfur concentrations, because some crystals displayed major element compositional zoning. Although we tried to analyze at least five crystals in each experiment, in some cases, this was impossible. Additionally, some of our analyses contained anomalously high sulfur concentrations indicative of an analysis of a mixture of crystal+glass, marked also by a higher $\mathrm{Cl}$ concentration. Such obviously incorrect analyses were removed from those used to calculate the mean sulfur concentrations of the crystals. In one case (CS2014-20) only one clinopyroxene analysis was deemed acceptable, but for most experiments, 1 three or more analyses were used for the calculation of the mean 2 and standard deviation (see Table 3). The compositions of the 3 melts and crystals obtained from all successful experiments are 4 reported in Table 3. The many anhydrous experiments at high 5 oxygen fugacity that produced crystals too small for microbeam 6 analysis were not considered. Notably, the melt compositions, 7 sulfur concentrations in clinopyroxenes, and the resulting parti- 8 tion coefficients for experiments DRB2012-29, $-35,-36,-37$, and 9 -38 were previously presented in Callegaro et al. (2014) and are 10 included in this study for comparison.

Crystal-melt equilibrium was assessed by comparing 12 measured Fe-Mg partitioning between crystals and melts with 13 previous studies. With one exception, the clinopyroxene-melt 14 Fe-Mg partitioning of the low oxygen fugacity experiments was 15 within 25 relative percent of values calculated following Putirka 16 (1999). Experiment CS2014-31, performed at $1000{ }^{\circ} \mathrm{C}$, is an 17 exception; we do not attribute its difference to disequilibrium, 18
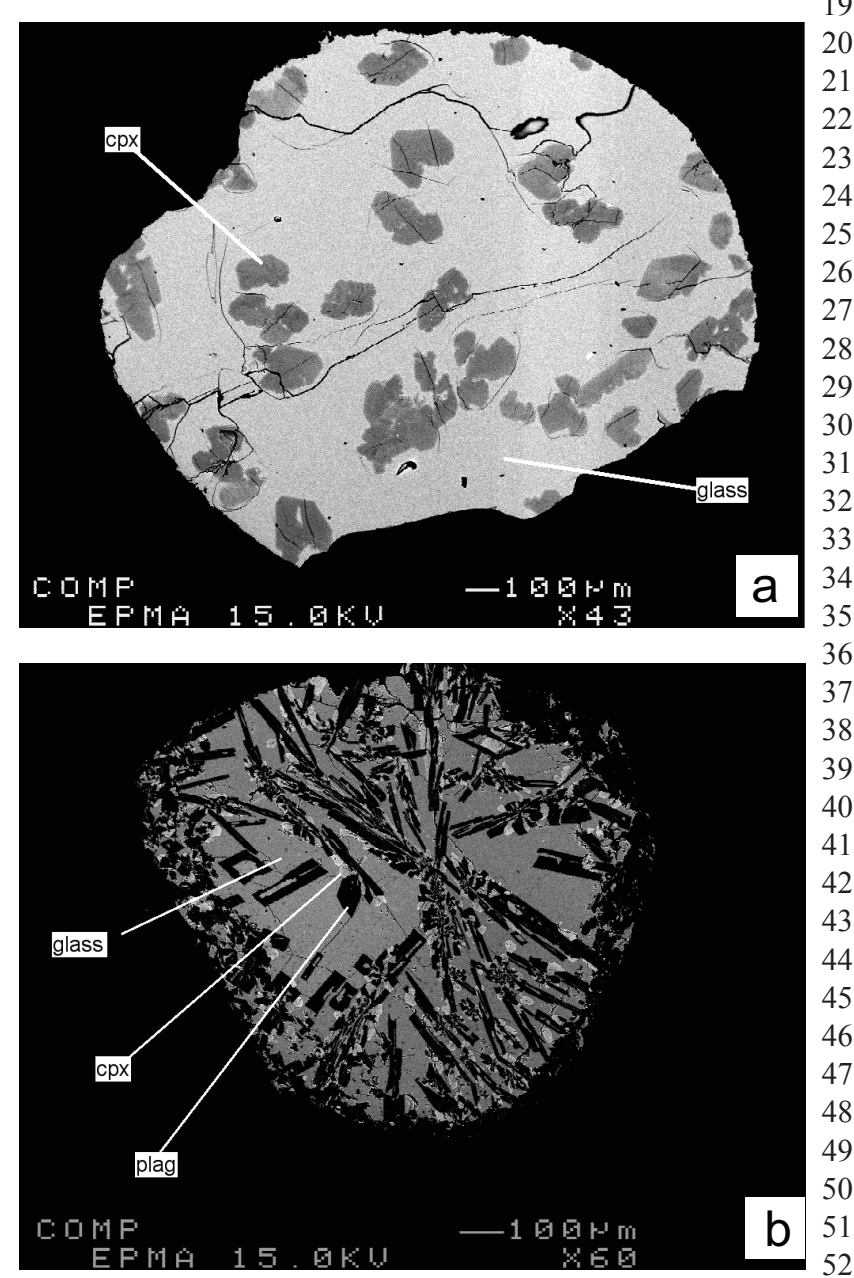

53

FIGURE 1. Backscattered electron images of two representative run 54 products. (a) Basaltic run product of experiment DRB2012-38 (1.2 GPa, 55 $1240^{\circ} \mathrm{C}$, anhydrous, low oxygen fugacity) containing clinopyroxene (Cpx) 56 and glass. (b) Andesitic run product of experiment CS2014-5 (0.8 GPa, 57 $1140{ }^{\circ} \mathrm{C}$, anhydrous, low oxygen fugacity) containing clinopyroxene, 57 plagioclase (Plag) and glass; the scale bar in this image is $200 \mu \mathrm{m}$.

\section{9} 0 21 22 23 24 26 27 28 29 0 1 3 (3) 6 
but to the fact that the experimental temperature is below the calibration range of Putirka's study, and the melt composition is richer in silica (66 wt\%) than the melts used in Putirka (1999) to calibrate $\mathrm{Fe}-\mathrm{Mg}$ partitioning equations. The Fe-Mg partitioning for both orthopyroxene and olivine in the low oxygen fugacity experiments of this study were similar to those previously measured for similar compositions at similar temperatures (Baker and Eggler 1987). On the other hand, the high oxygen fugacity experiments displayed partition coefficients significantly higher than expected from Putirka's (1999) calibration. We attribute this difference to the effect of oxygen fugacity on the ferric/ferrous ratio in both the melt and the crystal, a variable not included in Putirka's (1999) equations describing Fe-Mg partitioning between clinopyroxene and melt.

No intracrystalline heterogeneity was observed for sulfur, but many crystals were so small that only one analysis was made for each. Boyd's homogeneity index was used to assess the homogeneity of sulfur in the analyzed clinopyroxenes. According to Boyd et al. (1967), if the ratio of the relative standard deviation (based upon multiple analyses) to the relative uncertainty inherent in the analyses (e.g., the counting statistics) is above 3, it should be taken as highly suggestive of the presence of inhomogeneity in the material (see also Harries 2014). Potts et al. (1983) suggested that a higher value, above 4 , should be considered as the threshold between homogeneity and heterogeneity. We calculated Boyd's homogeneity index using the relative standard deviation about the mean of multiple $\mathrm{S}$ analyses on different crystals (Table 2) and a relative analytical uncertainty for concentrations greater than 6 ppm of 14\%, as calculated in the Analytical Techniques. Of the 13 clinopyroxene samples \{ \{auth: okay?\}\} analyzed, we find that 4 display a Boyd homogeneity index greater than 3 , but only 1 is greater than 4 (CS2014-13, with a value of 5.8). Thus, despite the large standard deviations seen for some analyses, the intercrystalline sulfur concentrations from each experiment do not display significant evidence of heterogeneity. Although CS201413 displays evidence of heterogeneity, we retain it because we believe that the mean sulfur concentration in the clinopyroxenes is a reliable estimate.

The fraction of sulfur as sulfate (as measured at the electron microprobe by the sulfur peak shift) in the high oxygen fugacity experiments varied from 0.33 to 0.73 , and their calculated oxygen fugacities range from FMQ+0.8 to FMQ+1.8 (Table 2). These high oxygen fugacities are consistent with the presence of Fe-Ti oxide minerals (e.g., CS2014-20 in Table 2) only in the high oxygen fugacity experiments. Additionally, only these experiments produced clinopyroxenes whose mineral formula calculations indicated the presence of ferric iron. Three low-oxygen-fugacity experiments (CS2014-9, -30, and -31) were also measured and found to have all sulfur dissolved as sulfide, consistent with previous measurements of sulfide speciation in anhydrous and hydrous melts in graphitelined Pt capsules (Fortin et al. 2015). Although the oxygen fugacity cannot be calculated for these low oxygen fugacity experiments, the lack of measurable sulfate indicates oxygen fugacities at, or below, the FMQ buffer, which following Fortin et al. (2015) we estimate as FMQ-2 in Table 2. The oxygen fugacity may possibly be lower, but its minimum value is constrained by the lack of metallic iron in the run products, i.e., the oxygen fugacity is above FMQ-4 at the conditions studied.

\section{Sulfur partitioning between clinopyroxene and melt}

The mean concentration of sulfur in the clinopyroxenes varied from a minimum of 9 to a maximum of 54 ppm (Table 2), and the corresponding partition coefficients varied from 0.017 to 0.0750 . Total sulfur partition coefficients are calculated by dividing the sulfur concentration in the crystal by the total sulfur concentration in the coexisting melt and are plotted as a function of the $\mathrm{SiO}_{2}$ concentration in the melt in Figure 2a. This figure demonstrates that with the exception of one hydrous experiment with a high- $\mathrm{SiO}_{2}$ melt (CS2014-31), the partition coefficients can be separated into low- $f_{\mathrm{O}_{2}}$ and high- $f_{\mathrm{O}_{2}}$ trends. Based upon the major element composition of the clinopyroxenes, approximately half were augitic and the other half pigeonitic. There appear to be no significant differences in the crystal-melt sulfur partition coefficients of augitic and pigeonitic clinopyroxenes; however, as discussed below, the $\mathrm{Fe} / \mathrm{Mg}$ ratio of the clinopyroxene appears to affect the total sulfur partition coefficient.

Five hydrous, clinopyroxene-bearing experiments were performed. The water concentrations in the melts varied from 1.1 to $11.2 \mathrm{wt} \% \mathrm{H}_{2} \mathrm{O}$ (Table 2). Comparison of the one hydrous experiment producing a basaltic melt with $7.6 \mathrm{wt} \% \mathrm{H}_{2} \mathrm{O}$ (DRB2015-1) with the anhydrous experiment at the same pressure and oxygen fugacity (CS2014-13) produced similar total sulfur partition coefficients (Fig. 2a, Table 2). The clinopyroxene/melt partition coefficient for a hydrous dacitic melt (CS2014-31) at low oxygen fugacity is within the uncertainty of the extrapolation of the high oxygen fugacity, hydrous partition coefficients (Fig. 2a). Two hydrous experiments at high $f_{\mathrm{O}_{2}}$ produced melts with andesitic compositions coexisting with clinopyroxene (CS201419, DRB2015-2). On the other hand, no anhydrous experiments at high $f_{\mathrm{O}_{2}}$ were successfully performed for andesitic compositions. Therefore, we cannot make any direct comparison between results from hydrous and anhydrous high $f_{\mathrm{O}_{2}}$ andesitic experiments (Fig. 2a). Overall, these results lead to a conundrum: the total sulfur partition coefficients for basaltic melts indicate that the difference in oxygen fugacity is responsible for the two trends in Figure 2a; instead the clinopyroxene-melt partition coefficients for the dacitic melt suggest that the presence of water may be responsible for the different trends.

The oxygen fugacity and compositional dependence of the sulfur partition coefficient can be removed if the partition coefficient is calculated by dividing the sulfur concentration of the crystal by the sulfide concentration in the melt, calculated from the shift of the sulfur peak and the bulk sulfur concentration (Table 2). When this is done, all of the $\mathrm{S}^{2-}$ partition coefficients show a weak correlation (Fig. 2b). However, the partition coefficients for the melts with silica concentrations below $\sim 51 \mathrm{wt} \%$ from Callegaro et al. (2014) all cluster slightly below the line suggesting the existence of a small compositional effect for clinopyroxenes crystallizing from low-silica melts. If the influence of these points is removed, the $\mathrm{S}^{2-}$ partition coefficient between clinopyroxene and melts with $\mathrm{SiO}_{2}$ higher than ca. $51 \mathrm{wt} \%$ can be calculated from the mean of the points in Figure 2b: $0.063 \pm 0.010$ ( $1 \sigma$ St.dev. about the mean).

\section{Partitioning of sulfur between melt and plagioclase}

Plagioclase crystallized in 7 experiments (Tables 2 and 3). However, as discussed below, one of the experiments appears to have crystallized plagioclase during quench, hence only six parti- 


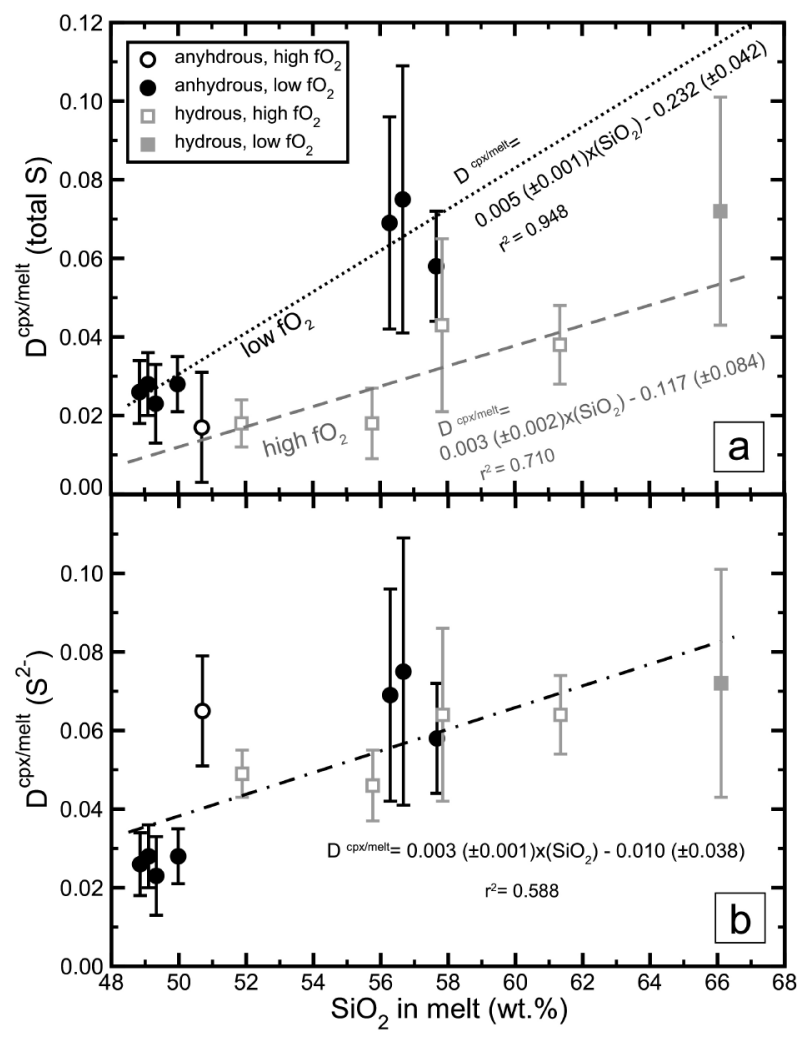

FiguRE 2. Correlation of sulfur clinopyroxene-melt partition coefficient, $D$, with melt composition at low and high oxygen fugacity as well as with and without added water. (a) Total sulfur partition coefficients for clinopyroxene-melt vs. silica concentration in the melt. Note that, with one exception, experiments at low $f_{\mathrm{O}_{2}}$ display higher partition coefficients (by a factor of approximately 3 ) than hydrous experiments at high $f_{\mathrm{O}_{2}}$, as discussed in the text. The stippled line labeled low $f_{\mathrm{O}_{2}}$ is fit through the anhydrous experiments performed in graphite capsules and the dashed line labeled high $f_{\mathrm{O}_{2}}$ is fit to hydrous experiments performed in gold-palladium capsules (see Table 2). (b) $\mathrm{S}^{2-}$ partition coefficient between clinopyroxene and melt as a function of the $\mathrm{SiO}_{2}$ concentration in the melt. Note that the two trends presented in a collapse into a single trend almost independent of the silica concentration in the melt, and that the $\mathrm{S}^{2-}$ partition coefficient appears constant for melts above approximately $51 \mathrm{wt} \% \mathrm{SiO}_{2}$. The uncertainties in the measured partition coefficients shown in this and subsequent figures are $1 \sigma$ uncertainties calculated from either the standard deviation about the mean (where multiple analyses were performed; see Table 2), or uncertainties calculated from counting statistics (where only single measurements were available). See text for further discussion.

tioning measurements are deemed reliable. The concentrations of sulfur in the crystals varied from 37 to $93 \mathrm{ppm}$ and the calculated total sulfur partition coefficients from 0.036 to 0.393 , but most of them are near the lower value (Fig. 3). In general, the partition coefficients for plagioclase were similar to, or slightly higher, than those for clinopyroxene. Most plagioclase crystals were in the compositional range of $\mathrm{An}_{40-45}$, although one $\mathrm{An}_{61}$ crystal formed in DRB2012-36. With the exception of a hydrous experiment at high $f_{\mathrm{O} 2}$ (CS2014-20), no influence of the anorthite content of the crystals or their iron concentration on the total sulfur partition coefficients was detected, nor was any influence of oxygen fugacity observed (Fig. 3). The few plagioclase crystals in the anomalous 1 experiment CS2014-20 with the high partition coefficient were 2 anhedral with morphologies suggestive of rapid growth during 3 quench, therefore we surmise that plagioclase-melt partition coef- 4 ficients for this experiment are not valid. The lack of observable 5 influence of crystal composition and oxygen fugacity is also true 6 when the $\mathrm{S}^{2-}$ partition coefficient is calculated (not shown). 7

\section{Partitioning of sulfur between melt and olivine or orthopyroxene}

Olivine and orthopyroxene crystallized in one and two anhy- 11 drous experiments, respectively (Tables 2 and 3). The concen- 12 trations of sulfur in the orthopyroxenes and olivines were near, 13 or at, the detection limits of the SXRF analysis. Consequently, 14 the corresponding total sulfur partition coefficients (which are 15 the same as the $\mathrm{S}^{2-}$ partition coefficients for the low oxygen 16 fugacity experiments because all sulfur is found in the $\mathrm{S}^{2-}$ state) 17 were significantly lower than those of clinopyroxene (Table 2). 18 The olivine in DRB2012-29 was at the detection limit of our 19 analysis with a $\mathrm{S}$ concentration of $1 \pm 0.2 \mathrm{ppm}$, yielding a maxi- 20 mum sulfur partition coefficient of 0.001 . The orthopyroxenes 21 that co-existed with a basaltic melt in the low oxygen fugacity 22 experiment DRB2012-29 (at $0.8 \mathrm{GPa}, 1240{ }^{\circ} \mathrm{C}$ ) contained $3 \pm 23$ $2 \mathrm{ppm} \mathrm{S}$, and produced a total sulfur orthopyroxene/melt $D$ of 24 0.003 . The orthopyroxene crystallized from a basaltic melt in 25 the high oxygen fugacity experiment (CS2014-14 at $1.0 \mathrm{GPa}, 26$ $1240{ }^{\circ} \mathrm{C}$ ) contained an average of $2 \pm 1 \mathrm{ppm} \mathrm{S}$; the total sulfur 27 partition coefficient is 0.002 and the $\mathrm{S}^{2-}$ partition coefficient is 28 0.007 . Because the sulfur concentrations in the orthopyroxene 29 and olivine are very close to the detection limit for SXRF 30 (approximately $1 \mathrm{ppm}$ ), their partition coefficients should be 31 considered maximum values.

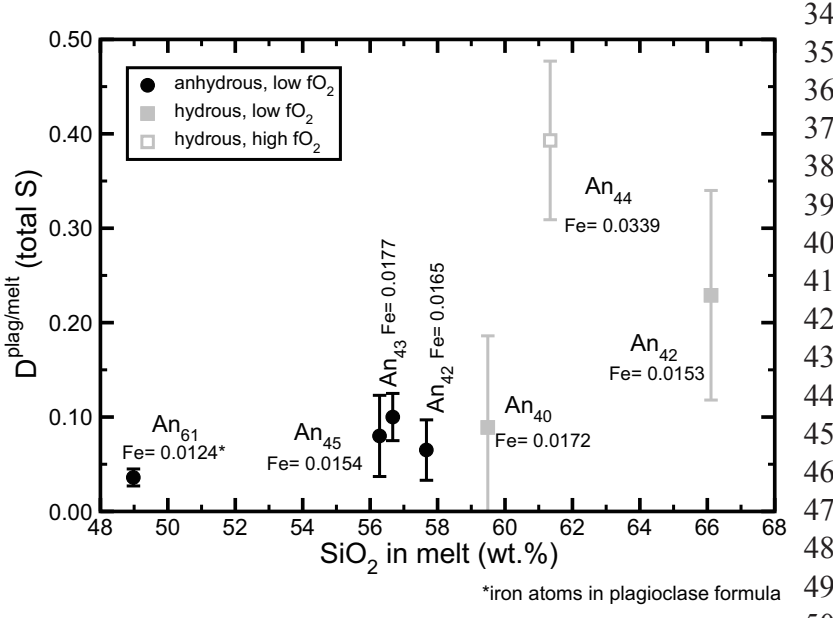

FIGURE 3. Total sulfur partition coefficients for plagioclase-melt 51 vs. silica concentration in the melt, at low and high oxygen fugacities 52 and with and without added water. Both the anorthite content and the 53 amount of iron in the plagioclase formula are displayed next to the 53 data points. The range in anorthite concentrations is too small to obtain 54 any meaningful relation between them and the partition coefficients, 55 and no clear dependence upon the silica concentration in the melt is 56 observed. (Note that as discussed in the text the value for the one hydrous 57 experiment at high oxygen fugacity should be considered unreliable.) 58 


\section{Partitioning of sulfur between melt and amphibole}

Amphibole crystallized in two hydrous experiments, CS201420 (at $0.8 \mathrm{GPa}, 1000^{\circ} \mathrm{C}$ and high oxygen fugacity) and CS2014-30 (at $0.8 \mathrm{GPa}, 1000^{\circ} \mathrm{C}$ and low oxygen fugacity). In CS2014-30 the average $S$ concentration in amphibole was $87 \pm 58$ ppm ( $1 \sigma$ St.dev.) and in CS2014-20 it was $29 \pm 14 \mathrm{ppm}$, which yielded total sulfur partition coefficients of 0.127 and 0.123 , and $\mathrm{S}^{2-}$ partition coefficients of 0.127 and 0.208 , respectively. These values are larger than measured in clinopyroxenes. However, the crystallization of amphibole in CS2014-30 is surprising due to the measured water concentration of only $1.1 \mathrm{wt} \%$ in the quenched glass, although the presence of halogens in the melt of this experiment may be responsible for the presence of amphibole (see review in Webster et al. 2018). Amphibole crystallizing at such a low water concentration might suggest the possibility of disequilibrium in CS2014-30; we cannot discount this possibility, but we decided to include this value because it is the only amphibole/melt partition coefficient measured at high oxygen fugacity.

\section{DiscuSSION}

\section{Influence of silicate mineral structure on $D$}

Although clear trends in the clinopyroxene/melt partition coefficients as a function of melt composition can be seen in Figure 2 , it is well known that the partition coefficients of trace elements are controlled more by crystal chemistry and structure than by melt composition (e.g., Blundy and Wood 1991). The total sulfur partition coefficients and the $\mathrm{S}^{2-}$ partition coefficients in Table 2 correlate with the average bond distance for the mean $\mathrm{M}(2)-\mathrm{O}$ distances in olivine, orthopyroxene, and clinopyroxene, with the mean $\mathrm{Ca}-\mathrm{O}$ distance in plagioclase, and with the mean $\mathrm{M}(4)-\mathrm{O}$ distance for a pargasitic hornblende (Fig. 4).

We propose that the dominant dissolution mechanism of sulfur is the replacement of some oxygen by $\mathrm{S}^{2-}$. This hypothesis is based upon the similar sizes and same charge of $\mathrm{S}^{2-}, 170 \mathrm{pm}$ in sixfold coordination and $\mathrm{O}^{2-}, 121 \mathrm{pm}$ in twofold coordination (Shannon 1976). This replacement also is suggested by the observation that the total partition coefficient between clinopyroxene and melt is significantly lower in experiments at high $f_{\mathrm{O}_{2}}$, where most sulfur in the melt is present as an $\mathrm{S}^{6+}$ species, as opposed to the low $f_{\mathrm{O}_{2}}$ experiments, where the sulfur in the melt is in an $\mathrm{S}^{2-}$ species (e.g., Fincham and Richardson 1954; Wilke et al. 2011). Furthermore, the near-constant value of the clinopyroxene-melt $\mathrm{S}^{2-}$ partition coefficient is seen in Figure 2b, despite variations in melt composition, water concentration, and oxygen fugacity, is more easily explained if $\mathrm{S}^{2-}$ is exchanging between the crystals and the melts.

The correlation between the bond lengths and the sulfur crystal/ melt partition coefficient (Fig. 4) is interpreted to indicate that crystallographic sites with average cation-oxygen bond lengths greater than $220 \mathrm{pm}$ are necessary to accommodate substantial amounts of sulfur, greater than a few parts per million, and that sulfur replaces some of the oxygen coordinating the $\mathrm{M}(2)$ sites in olivine, orthopyroxene, and clinopyroxene, some oxygen coordinating the alkalis and alkali earths in plagioclase, and oxygen coordinating the M(4) site in amphibole.

The sulfur partitioning (Fig. 4) also positively correlates with an increasing fraction of bridging $\mathrm{O}$ atoms in the crystal structure. However, the replacement of bridging $\mathrm{O}$ atoms by sulfur seems

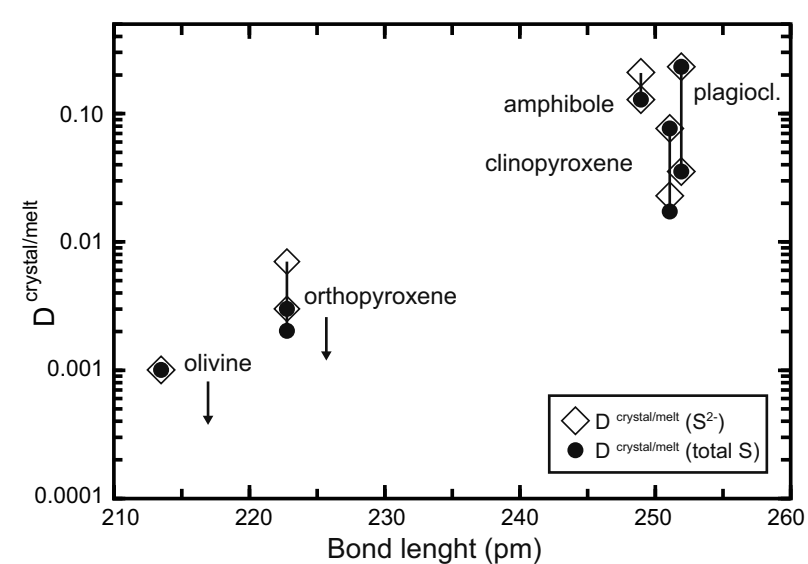

$\mathrm{M}(2)-\mathrm{O}$ in ol, opx, and cpx; $\mathrm{M}(4)-\mathrm{O}$ in pargasite; $\mathrm{Ca}-\mathrm{O}$ in plagioclase

FigURE 4. Correlation between the range of total sulfur and $\mathrm{S}^{2-}$ partition coefficients presented in Table 2 and the size of the M(2)-oxygen bond-length in olivine (Brown 1980 \{ \{auth: not listed in Ref list please add or fix\}\}), orthopyroxene (Cameron and Papike 1980\{\{auth: not listed in Ref list please add or fix $\}\}$ ), and clinopyroxene (Cameron and Papike 1980), the M(4)-oxygen bond-length in pargasite (Robinson et al. 1973), and the Ca-O bond-length in anorthitic plagioclase (Wainwright and Starkey 1971\{ \{auth: not listed in Ref list please add or fix\}\}; Smyth $1986\{$ \{auth: not listed in Ref list please add or fix \}\}). The vertical lines connect the minimum and maximum partition coefficients measured for each mineral in this study. The arrows associated with olivine and orthopyroxene indicate that these are to be considered maximum values of the partition coefficients. See text for further discussion.

improbable because in this case the similar T-O bond lengths of the minerals would suggest similar partition coefficients, which is not seen in Figure 4.

\section{Influence of clinopyroxene composition on $D$}

When the total sulfur partition coefficients are plotted as a function of the $\mathrm{Mg} \#$, molecular $\mathrm{Mg} /\left(\mathrm{Mg}+\mathrm{Fe}^{\text {total }}\right)$ of clinopyroxenes crystallized in these experiments, two trends can be observed - one for low and one for high oxygen fugacity (Fig. 5a). However, when the $\mathrm{S}^{2-}$ partition coefficients are plotted against the clinopyroxene $\mathrm{Mg \# ,} \mathrm{only} \mathrm{a} \mathrm{weak} \mathrm{correlation} \mathrm{is} \mathrm{vis-}$ ible (Fig. 5b). Most of that dependency is due to the results of Callegaro et al. (2014) at high $\mathrm{Mg} \#$ values, where it appears that most clinopyroxene/melt $\mathrm{S}^{2-}$ partition coefficients are within the uncertainty of each other (Fig. 2b), as was previously observed for the effect of melt composition. However, a small negative dependency of the sulfur partition coefficients (total and $\mathrm{S}^{2-}$ ) on the $\mathrm{Mg \#}$ might be expected because as iron substitutes for magnesium in the structures of ferromagnesian minerals, the cation-oxygen bond distances get slightly longer (Cameron and Papike 1980). In contrast to the possible small effect of Mg\# on partitioning, our results provide no evidence that ${ }^{\mathrm{IV}} \mathrm{Al}$ plays a role on sulfur partitioning (Fig. 5c). Such an effect has been hypothesized and investigated for halogen partitioning between clinopyroxene and melt (O'Leary et al. 2010; Rosenthal et al. 2015; Urann et al. 2017; Bénard et al. (2017). Our observations are similar to those of Rosenthal et al. (2015) who found no significant effect of ${ }^{\mathrm{IV}} \mathrm{Al}$ in their partitioning measurements of halogens between clinopyroxene and melt. 
Comparison between $\mathrm{S}$ partitioning and $\mathrm{H}, \mathrm{C}, \mathrm{F}$, and $\mathrm{Cl}$ partitioning between nominally volatile-free crystals and melts

The partition coefficients of total sulfur and $\mathrm{S}^{2-}$ between nominally volatile-free minerals (NVFMs) and silicate melts are typically lower than those of fluorine, higher than those of carbon, and similar to those of chlorine and hydrogen (Fig. 6). Hydrogen, fluorine, and chlorine display similar trends in the value of the partition coefficient as seen for sulfur in ferromagnesian crystals (Figs. 6). Indeed, the crystal/melt partition coefficients for each of these elements increase in the order: olivine $<$ orthopyroxene $<$ clinopyroxene.

The plagioclase/melt fluorine partition coefficients are similar to those of clinopyroxene and amphibole, whereas $\mathrm{H}$ and $\mathrm{Cl}$ plagioclase/melt partition coefficients are more than one order of magnitude lower (Fig. 6). The hydrous mineral amphibole displays significantly higher partition coefficients of $\mathrm{Cl}, \mathrm{H}$, and $\mathrm{F}$ than the other ferromagnesian crystals and plagioclase because of the structural role of these volatiles in the amphibole crystal lattice (Fig. 6).

The similar crystal/melt partitioning of $\mathrm{H}, \mathrm{F}, \mathrm{S}$, and $\mathrm{Cl}$ supports the hypothesis that the dissolution mechanism of these elements into silicate minerals is similar and occurs probably either as a replacement of an oxygen atom $(\mathrm{F}, \mathrm{Cl}$, and $\mathrm{S})$ or by association with an oxygen atom $(\mathrm{H})$.

In contrast to these volatiles, the partition coefficient of carbon between melt and olivine, orthopyroxene, or clinopyroxene appears to be approximately constant, although orthopyroxene may have a lower partition coefficient than either olivine or clinopyroxene

(Fig. 6). However, this behavior needs further investigation because 1 of the relatively large uncertainties in the partition coefficients 2 derived from the very low $\mathrm{S}$ concentrations in these crystals. The 3 unique behavior of carbon in comparison to the other elements in 4 Figure 6 suggests a different dissolution mechanism, but discussion 5 of this mechanism is far beyond the scope of this contribution. 6

\section{IMPLICATIONS: SULFUR PARTITIONING APPLIED TO 8 NATURAL MAGMATIC SYSTEMS}

The proposed crystal/melt partition coefficients for sulfur com- 10 bined with previously published ones for hydrogen, carbon, fluorine, 11 and chlorine can be used to provide insights into the concentrations 12 of the igneous quintet of major volatiles in magmatic systems. 13

Estimating the pristine volatile budget of a magma that has 14 already solidified is challenging, and this is particularly true for 15 sulfur, carbon, and water, which are degassed earlier than fluorine 16 or chlorine in the eruptive history of magmas (e.g., Spilliaert et al. 17 2006). Therefore, quantitative estimates of gas budgets in melts from 18 past eruptions are still scarce because of the rarity of melt inclusions, 19 which are the primary means of determining pre-eruptive volatile 20 concentrations in magmatic melts (e.g., Devine et al. 1984; Johnson 21 et al. 1994; Cannatelli et al. 2016). In the absence of melt inclusions, 22 the magma volatile budget may be determined by a combination of 23 the measurement of volatile concentrations in natural minerals with 24 experimentally determined partition coefficients (mineral/melt $D$ ). 25 The challenge in this case is set by the low concentration of volatiles 26 in the crystals, typically at the parts-per-million level in NVFMs, such 27

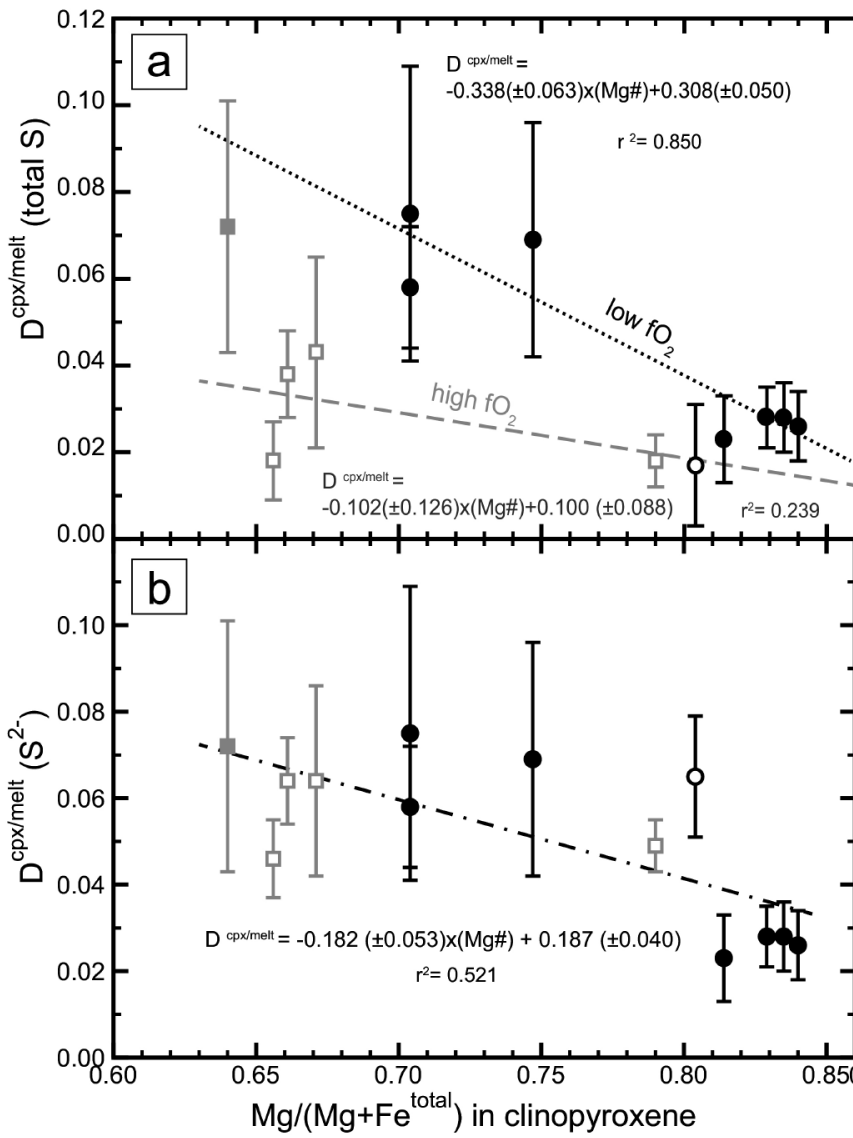

4FIGURE 5. Effect of clinopyroxene composition on the sulfur $D$. 30 (a) Correlation between the total sulfur partition coefficient and 31 the $\mathrm{Mg} /\left(\mathrm{Mg}+\mathrm{Fe}^{\text {total }}\right)$ in the clinopyroxene. The low $f_{\mathrm{O}_{2}}$ experiments 32 define a trend distinctly different from experiments at high $f_{\mathrm{O}_{2}} .33$ Note that the low $f_{\mathrm{O}_{2}}$ regression line (stippled) was fit only through 33 the anhydrous results at low oxygen fugacity and the high $f_{\mathrm{O}_{2}} 34$ regression line (dashed) only through the hydrous results at 35 high oxygen fugacity. (b) Relationship between the $\mathrm{S}^{2-}$ partition 36 coefficient and the $\mathrm{Mg} \#$ of the clinopyroxene. The two trends 37 seen in a for the total sulfur partition coefficient collapse into 38 a single trend in $\mathbf{b}$ that is at most slightly dependent upon the 39 $\mathrm{Mg} \#$ of the clinopyroxene. (c) No correlation is visible between 40 the $\mathrm{S}^{2-}$ clinopyroxene-melt partition coefficient and the ${ }^{\mathrm{IV}} \mathrm{Al}$ in 41 clinopyroxene. See text for further discussion. 


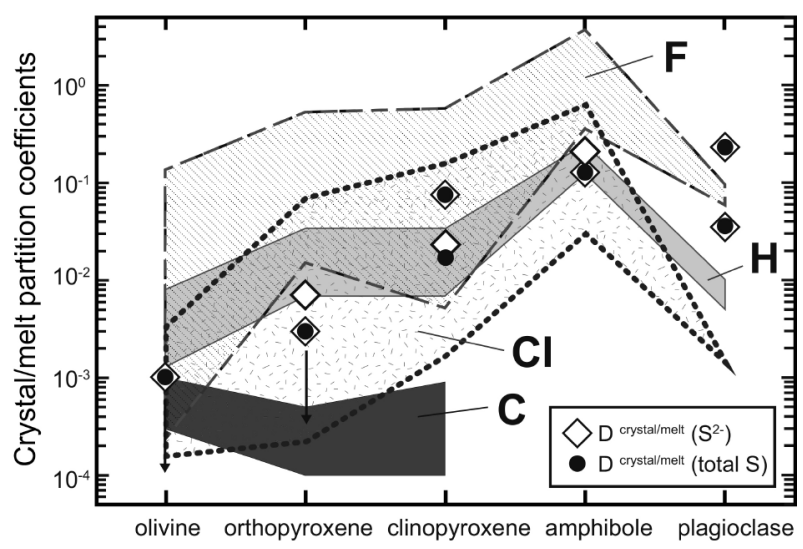

FIGURE 6. Partition coefficients (Table 2) for total sulfur (black circles) and $\mathrm{S}^{2-}$ (open diamonds) measured in this study and in Callegaro et al. (2014), compared to those obtained for carbon and hydrogen as water (Hauri et al. 2006; Hamada et al. 2013; Rosenthal et al. 2015; Lloyd et al. 2016) and for fluorine and chlorine (Hauri et al. 2006; O'Leary et al.2010; Dalou et al. 2012, 2014; Guggino 2012; Beyer et al. 2012 \{ \{auth: not listed in Ref list please add or fix\}\}, 2016; Van den Bleeken and Koga 2015; Bénard et al. 2017; Lloyd et al. 2016). Minimum and maximum sulfur partition coefficients are plotted for clinopyroxene, amphibole, and plagioclase. The arrows below the sulfur partition coefficients for olivine and orthopyroxene indicate that the plotted values are considered maxima.

as olivine, orthopyroxene, clinopyroxene, and plagioclase, and by the availability of partition coefficients. The sulfur partition coefficients measured in this study can be combined with measurements of natural crystals to determine the concentration of sulfur in coexisting melts from which the minerals crystallized. Given the measurement of sulfur in a crystal and knowledge of the oxygen fugacity of crystallization, the $\mathrm{S}^{2-}$ partition coefficients determined in this study can be used to calculate the $\mathrm{S}^{2-}$ concentrations in the melt. This value can be combined with the $\mathrm{S}^{6+} / \mathrm{S}^{2-}$ ratio (Wilke et al. 2011) to calculate total sulfur in the melt. This technique allows determination of sulfur in coexisting melts ranging in oxygen fugacity from the FMQ buffer to more reduced conditions, such as the dominant magmas on Earth, MORBs, and those associated with Large Igneous Provinces. However, our newly established partition coefficients can be applied also to magmas with oxidation states near FMQ +2 , typically found at convergent margins (Carmichael 1991).

On the other hand, if the oxidation state is not known, the total sulfur partition coefficients for reduced or oxidized conditions can be used.

These partition coefficients will allow calculation of the sulfur budget of ancient natural basalts, particularly those constituting Large Igneous Provinces (LIPs), whose timing often coincides with mass extinction events (Wignall 2001; Bond and Wignall 2014). Quantifying gas loads and rates of degassing for LIP magmas is fundamental to understand this causal relationship, and particular attention, through analyses or models, has been recently directed to sulfur (e.g., Self et al. 2008, 2014; Callegaro et al. 2014; Jones et al. 2016; Schmidt et al. 2016).

We stress however that we are working with $\mathrm{S}$ concentrations very close to the detection limits of the SXRF technique; therefore the uncertainties involved are very large. A further characterization of standards will help reduce the uncertainties in the future, but at present we advise that the here proposed partition coefficients should be applied only to analyses carried out by the same analytical technique (SXRF), as well as the same data reduction routine (PYMCA). Thanks to fast acquisition times and small spot size (few square micrometers), SXRF provides the opportunity to map sulfur in crystals and to potentially discover evidence of degassing episodes or magma mixing events (i.e., $\mathrm{S}$ loss or $\mathrm{S}$ uptake by the system) during crystal growth, an application of great interest in the study of active volcanic systems.

\section{ACKNOWLEDGMENTS AND FUNDING}

We thank two anonymous reviewers for their insightful suggestions and $\mathrm{K}$. Iacovino for her comments on an earlier version of this manuscript. This research was supported by an NSERC Discovery Grant to D.R.B. and by the 2014 SIMP prize grant dedicated to the memory of E.M. Piccirillo awarded to S.C. Further support from PRIN (PRIN 20178LPCP) to A. Marzoli is gratefully acknowledged. The synchrotron measurements were supported by Diamond Light Source.

\section{REFERENCES CITED}

Baker, D.R. (2004) Piston cylinder calibration at 400 to $500 \mathrm{MPa}$ : a comparison of using water solubility in albite melt and $\mathrm{NaCl}$ melting. American Mineralogist, $89,1553-1556$.

(2008) The fidelity of melt inclusions as records of melt composition. Contributions to Mineralogy and Petrology, 157, 377-395.

Baker, D.R., and Alletti, M. (2012) Fluid saturation and volatile partitioning between melts and hydrous fluids in crustal magmatic systems: The contribution of experimental measurements and solubility models. Earth-Science Reviews, 114, 298-324. $\{$ \{auth: not called out in paper, unless it is called out in deposit material please add or delete from list\}\}

Baker, D.R., and Eggler, D.H. (1987) Compositions of anhydrous and hydrous melts coexisting with plagioclase, augite, and olivine or low-Ca pyroxene from $1 \mathrm{~atm}$. to 8 kbar: application to the Aleutian volcanic center of Atka. American Mineralogist, $72,12-28$.

Baker, D.R., and Moretti, R. (2011) Modeling the solubility of sulfur in magmas: a 50-year old geochemical challenge. In H. Behrens and J.D. Webster, Eds., Sulfur in Magmas and Melts and its Importance for Natural and Technical Processes. Reviews in Mineralogy and Geochemistry, 73, 167-213. \{ \{auth: not called out in paper, unless it is called out in deposit material please add or delete from list $\}$ \}

Bénard, A., Koga, K.T., Shimizu, N., Kendrick, M.A., Ionov, D.A., Nebel, O., and Arculus, R.J. (2017) Chlorine and fluorine partition coefficients and abundances in sub-arc mantle xenoliths (Kamchatka, Russia): Implications for melt generation and volatile recycling processes in subduction zones. Geochimimica and Cosmochimica Acta, 199, 324-350.

Beyer, C., Klemme, S., Grützner, T., Ireland, T.R., Magee, C.W., and Frost, D.J. (2016) Fluorine partitioning between eclogitic garnet, clinopyroxene, and melt at upper mantle conditions. Chemical Geology, 437, 88-97.

Black, B.A., Elkins-Tanton, L.T., Rowe, M.C., and Peate, I.U. (2012) Magnitude and consequences of volatile release from the Siberian Traps. Earth and Planetary Science Letters, 317-318, 363-373.

Blundy, J.D. and Wood, B.J. (1991) Crystal-chemical controls on the partitioning of Sr and $\mathrm{Ba}$ between plagioclase feldspar, silicate melts, and hydrothermal solutions. Geochimica and Cosmochimica Acta, 55, 193-209.

Bond, D.P.G., and Wignall, P.B. (2014) Large igneous provinces and mass extinctions: An update. Geological Society of America Special Papers, 505, 29-55.

Boyd, F.R., Finger, L.W., and Chayes, F. (1967) Computer reduction of electron-probe data. Carnegie Institution of Washington Year Book, 67, 210-215.

Callegaro, S., Baker, D.R., de Min, A., Marzoli, A., Geraki, K., Bertrand, H., Viti, C., and Nestola, F. (2014) Microanalyses link sulfur from large igneous provinces and Mesozoic mass extinctions. Geology, 42, 895-898.

Cannatelli, C., Doherty, A.L., Esposito, R., Lima, A., and De Vivo, B. (2016) Understanding a volcano through a droplet: A melt inclusion approach. Journal of Geochemical Exploration, 171, 4-19.

Carmichael, I.S.E. (1991) The redox states of basic and silicic magmas: a reflection of their source regions? Contributions to Mineralogy and Petrology, 106, 129-141.

Carroll, M.R., and Rutherford, M.J. (1988) Sulfur speciation in hydrous experimental galsses of varying oxidation sates: results from measured vavelength shifts of sulfur X-rays. American Mineralogist, 73, 845-849.

Dalou, C., Koga, K.T., Shimizu, N., Boulon, J., and Devidal, J.-L. (2012) Experimental determination of $\mathrm{F}$ and $\mathrm{Cl}$ partitioning between lherzolite and basaltic melt. Contributions to Mineralogy and Petrology, 163, 591-609.

Dalou, C., Koga, K.T., Le Voyer, M., and Shimizu, N. (2014) Contrasting partition behavior of $\mathrm{F}$ and $\mathrm{Cl}$ during hydrous mantle melting: implications for $\mathrm{Cl} / \mathrm{F}$ signature in arc magmas. Progress in Earth and Planetary Science, 1, 26.

Dalpé, C. and Baker, D.R. (2000) Experimental investigation of LILE, HFSE, and REE partitioning between calcic amphibole and basaltic melt: The effects of pressure 
and oxygen fugacity. Contributions to Mineralogy and Petrology, 140, 233-250.

DeHoog, J.C.M., Mason, P.R.D., and Van Bergen, M.J. (2001) Sulfur and chalcophile elements in subduction zones: Constraints from a laser ablation ICP-MS study of melt inclusions from Galunggung volcano, Indonesia. Geochimica et Cosmochimica Acta, 65, 3147-3164.

Devine, J.D., Sigurdsson, H., Davis, A.N., and Self, S. (1984) Estimates of sulfur and chlorine yield to the atmosphere from volcanic eruptions and potential climatic effects. Journal of Geophysical Research: Solid Earth, 89, 6309-6325.

Erdman, M.E., Lee, C.-T.A., Yang, W., and Ingram, L. (2014) Sulfur concentration in geochemical reference materials by solution inductively coupled plasma-mass spectrometry. Geostandards and Geoanalytical Research, 38, 51-60.

Fincham, C.J., and Richardson, F.D. (1954) The behaviour of sulphur in silicate and aluminate melts. Proceedings of the Royal Society of London, 223A, 40-61.

Fortin, M.-A., Riddle, J., Desjardins-Langlais, Y., and Baker, D.R. (2015) The effect of water on the sulfur concentration at sulfide saturation (SCSS) in natural melts. Geochimica et Cosmochimica Acta, 160, 100-116.

Freda, C., Baker, D.R., and Ottolini, L. (2001) Reduction of water loss from goldpalladium capsules during piston-cylinder experiments by use of pyrophyllite powder. American Mineralogist, 86, 234-237.

Goldstein, J., Newbury, D.E., Joy, D.C., Lyman, C.E., Echlin, P., Lifshin, E., Sawyer, L. and Michael, J.R. (2003) Scanning Electron Microscopy and X-ray Microanalysis, $3^{\text {rd }}$ ed., 690 p. Springer.

Guggino, S.N. (2012) Fluorine partitioning between nominally anhydrous minerals (olivine, clinopyroxene, and plagioclase) and silicate melt using secondary ion mass spectrometry and newly synthesized basaltic fluorine microanalytical glass standards, 266 p., Ph.D. thesis, Arizona State University, Tempe.

Hamada, M., Ushioda, M., Fujii, T., and Takahashi, E. (2013) Hydrogen concentration in plagioclase as a hygrometer of arc basaltic melts: Approaches from melt inclusion analyses and hydrous melting experiments. Earth and Planetary Science Letters, 365, 253-262.

Harries, D. (2014) Homogeneity testing of microanalytical reference materials by electron probe microanalysis (EPMA). Chemie der Erde, 74, 375-384.

Hartley, M.E., Shorttle, O., Maclennan, J., Moussallam, Y., and Edmonds, M. (2017) Olivine-hosted melt inclusions as an archive of redox heterogeneity in magmatic systems. Earth and Planetary Science Letters, 479, 192-205.

Hauri, E.H., Gaetani, G.A., and Green, T.H. (2006) Partitioning of water during melting of the Earth's upper mantle at $\mathrm{H}_{2} \mathrm{O}$-undersaturated conditions. Earth and Planetary Science Letters, 248, 715-734.

Hill, R., and Roeder, P. (1974) The crystallization of spinel from basaltic liquid as a function of oxygen fugacity. The Journal of Geology, 82, 709-729.\{\{auth: not called out in paper, unless it is called out in deposit material please add or delete from list $\}$ \}

Jarosewich, E., Nelen, J.A., and Norberg, J.A. (1980) Reference samples for electron microprobe analysis. Geostandards Newsletter, 4, 43-47.

Johnson, M.C, Anderson, A.T. Jr., Rutherford, M.J. (1994) Pre-eruptive volatile contents of magmas. In M.R. Carroll and J.R. Holloway, Eds., Volatiles in Magmas. Reviews in Mineralogy, 30, 281-330.

Johnson, E.R., Wallace, P.J., Delgado Granados, H., Manea, V.C., Kent, A.J.R., Bindeman, I.N., and Donegan, C.S. (2009) Subduction-related volatile recycling and magma generation beneath Central Mexico: Insights from melt inclusions, oxygen isotopes and geodynamic models. Journal of Petrology, 50, 1729-1764.

Jones, M.T., Jerram, D.A., Svensen, H.H., and Grove, C. (2016) The effects of large igneous provinces on the global carbon and sulphur cycles. Palaeogeography, Palaeoclimatology, Palaeoecology, 441, 4-21.

La Tourrette, T., Hervig, R.L., and Holloway, J.R. (1995) Trace element partitioning between amphibole, phlogopite, and basanite melt. Earth and Planetary Science Letters, 135, 13-30.

LeVoyer, M., Cottrell, E., Kelley, K.A., Brounce, M., and Hauri, E.H. (2014) The effect of primary versus secondary processes on the volatile content of MORB glasses: An example from the equatorial Mid-Atlantic Ridge $\left(5^{\circ} \mathrm{N}-3^{\circ} \mathrm{S}\right)$. Journal of Geophysical Research: Solid Earth, 120, 125-144.

Lloyd, A.S., Ferriss, E., Ruprecht, P., Hauri, E.H., Jicha, B.R., and Plank, T. (2016) An assessment of clinopyroxene as a recorder of magmatic water and magma ascent rate. Journal of Petrology, 57, 1865-1886.

Liu, Y., Samaha, N.-T., and Baker, D.R. (2007) Sulfur concentration at sulfide saturation (SCSS) in magmatic silicate melts. Geochimica et Cosmochimica Acta, 71, 1783-1799.

Marzoli, A., Bertrand, H., Youbi, N., Callegaro, S., Merle, R., Reisberg, L., Chiaradia, M., Brownlee, S.I., Jourdan, F., Zanetti, A., and others. (2019) The Central Atlantic Magmatic Province (CAMP) in Morocco. Journal of Petrology, 60, 945-996.

Médard, E., McCammon, C.A., Barr, J.A., and Grove, T.L. (2008) Oxygen fugacity, temperature reproducibility, and $\mathrm{H}_{2} \mathrm{O}$ contents of nominally anhydrous piston-cylinder experiments using graphite capsules. American Mineralogist, 93, 1838-1844.

Mosselmans, J.F.W., Quinn, P.D., Dent, A.J., Cavill, S.A., Moreno, S.D., Peach, A., Leicester, P.J., Keylock, S.J., Gregory, S.R., Atkinson, K.D., and others. (2009) I18-the microfocus spectroscopy beamline at the Diamond Light Source. Journal of Synchrotron Radiation, 16, 818-824.

O'Leary, J.A., Gaetani, G.A., and Hauri, E.H. (2010) The effect of tetrahedral Al ${ }^{3+}$ on the partitioning of water between clinopyroxene and silicate melt. Earth and Planetary Science Letters, 297, 111-120.
Potts, P.J., Tindle, A.G., and Isaacs, M.C. (1983) On the precision of electron microprobe 1 data; a new test for the homogeneity of mineral standards. American Mineralogist, 2 $68,1237-1242$.

Robinson, K., Gibbs, G.V., Ribbe, P.H., and Hall, M.R. (1973) Cation distribution in 3 three hornblendes. American Journal of Science, 273A, 522-535.

Robock, A. (2013) The latest on volcanic eruptions and climate. EOS, 94, 305-307.

Rose-Koga, E.F., Koga, K.T., Moreira, M., Vlastelic, I., Jackson, M.G., Whitehouse, 5 M.J., and Habib, N. (2017) Geochemical systematics of Pb isotopes, fluorine, and 6 sulfur in melt inclusions from São Miguel, Azores. Chemical Geology, 458, 22-37. 7

Rosenthal, A., Hauri, E.H., and Hirschmann, M.M. (2015) Experimental determination of $\mathrm{C}, \mathrm{F}$, and $\mathrm{H}$ partitioning between mantle minerals and carbonated basalt, $\mathrm{CO}_{2} / \mathrm{Ba} 8$ and $\mathrm{CO}_{2} / \mathrm{Nb}$ systematics of partial melting, and the $\mathrm{CO}_{2}$ contents of basaltic source 9 regions. Earth and Planetary Science Letters, 412, 77-87.

Rousseau, R.M. (2001) Detection limit and estimate of uncertainty of analytical XRF 10 results. The Rigaku Journal, 18, 33-47.

Ruscitto, D.M. Wallace, P. J., Johnson, E R, Kent, A.J.R, and Bindeman, IN (2010) 12 Volatile contents of mafic magmas from cinder cones in the Central Oregon High 12 Cascades: Implications for magma formation and mantle conditions in a hot arc. 13 Earth and Planetary Science Letters, 298, 153-161.\{\{auth: not called out in 14 paper, unless it is called out in deposit material please add or delete from list \}\} 15

Schmidt, A., Skeffington, R.A., Thordarson, T., Self, S., Forster, P.M., Rap, A., Ridgwell, A., Fowler, D., Wilson, M., Mann, G.W., and others. (2016) Selective 16 environmental stress from sulphur emitted by continental flood basalt eruptions. 17 Nature Geoscience, 9, 77-82.

Self, S., Blake, S., Sharma, K., Widdowson, M., and Sephton, S. (2008) Sulfur and 18 chlorine in late Cretaceous. Science, 319, 1654-1657.

Self, S., Schmidt, A., and Mather, T.A. (2014) Emplacement characteristics, time scales, 20 and volcanic gas release rates of continental flood basalt eruptions on Earth. In G. Keller and A.C. Kerr, Eds., Volcanism, Impacts, and Mass Extinctions: Causes and Effects, 505, 319-337. Geological Society of America Special Paper.

Shannon, R.D. (1976) Revisedeffectiveionic radii and systematicstud distances in halides and chalcogenides. Acta Crystallographica, 32, 751-767.

Sibik, S., Edmonds, M., Maclennan, J., and Svensen, H.H. (2015) Magmas erupted 24 during the main pulse of Siberian Traps volcanism were volatile-poor. Journal of 25 Petrology, 56, 2089-2116.

Solé, V.A., Papillon, E., Cotte, M., Walter, P., and Susini, J. (2007) A multiplatform code 26 for the analysis of energy-dispersive X-ray fluorescence spectra. Spectrochimica 27 Acta Part B: Atomic Spectroscopy, 62, 63-68.

Spilliaert, N., Métrich, N., and Allard, P. (2006) S-Cl-F degassing pattern of water-rich 28 alkali basalt: Modelling and relationship with eruption styles on Mount Etna volcano. 29 Earth and Planetary Science Letters, 248, 772-786.

Symonds, R.B., Rose, WI., Bluth, G.S., and Gerlach, T ies, methods, results and applications. In M.R. Carroll and J.R. Holloway, Eds., 31 Volatiles in Magmas, 30, 1-66. Reviews in Mineralogy, Mineralogical Society of 32 America, Chantilly, Virginia.

Urann, B.M., Le Roux, V., Hammond, K., Marschall, H.R., Lee, C.T.A., and Monteleone, B.D. (2017) Fluorine and chlorine in mantle minerals and the halogen budget of the 34 Earth's mantle. Contributions to Mineralogy and Petrology, 172, 1-17.

Van den Bleeken, G., and Koga, K.T. (2015) Experimentally determined distribution of 36 fluorine and chlorine upon hydrous slab melting, and implications for $\mathrm{F}-\mathrm{Cl}$ cycling 37 through subduction zones. Geochimica and Cosmochimica Acta, 171, 353-373. 37

Wallace, P.J., and Edmonds, M. (2011) The sulfur budget in magmas: Evidence from melt 38 inclusions, submarine glasses, and volcanic gas emissions. Reviews in Mineralogy 39 and Geochemistry, 73, 215-246.

Webster, J.D., and Botcharnikov, R.E. (2011) Distribution of sulfur between melt and 40 fluid in SOCH-Cl-bearing magmatic systems at shallow crustal pressures and 41 temperatures. Reviews in Mineralogy, 73, 247-283. \{ \{auth: not called out in 42 paper, unless it is called out in deposit material please add or delete from list $\}$ \} 42

Webster, J.D., Baker, D.R., and Aiuppa, A. (2018) Halogens in mafic and intermediate- 43 silica content Magmas. The role of halogens in terrestrial and extraterrestrial geo- 44 chemical processes. In D.E. Harlov and L. Aranovich, Eds., The Role of Halogens in Terrestrial and Extraterrestrial Geochemical Processes, \{ \{auth: page numbers of chapter used $\}$ \} Springer Geochemistry.

Wignall, PB. (2001) Large igneous provinces and mass extinctions. Earth-Science Reviews, 53, 1-33.

Wilke, M., Klimm, K., and Kohn, S.C. (2011) Spectroscopic studies on sulfur specia- 48 tion in synthetic and natural glasses. In H. Behrens and J.D. Webster, Eds, Sulfur 49 in Magmas and Melts and its Importance for Natural and Technical Processes. 50 Reviews in Mineralogy and Geochemistry, 73, 41-78.

MANUSCRIPT RECEIVED JULY 1, 2019

MANUSCRIPT ACCEPTED DECEMBER 20, 2019

MANUSCRIPT HANDLED BY BRUCE WATSON

\section{Endnote:}

${ }^{1}$ Deposit item AM-20-57188, Supplemental Material. Deposit items are free to 56 all readers and found on the MSA website, via the specific issue's Table of Con- 57 tents (go to http://www.minsocam.org/MSA/AmMin/TOC/2020/May2020 data/ May2020_data.html).

11
3
4
5
6
17
8
9

